\title{
The Heavenly Master Liturgical Agenda According to Chisong zi's
}

\section{Petition Almanac}

\section{Franciscus Verellen}

\section{Résumé}

La tradition liturgique examinée dans cet article émane de la communauté dite des Maîtres célestes, première organisation ecclésiastique du taoïsme, qui perdure depuis le deuxième siècle apr. J.-C. jusqu'à nos jours. Au cœur du programme liturgique circonstancié de la communauté primitive, le rituel de présentation de requêtes est un modèle adaptable à tous les besoins. Le manuel normatif de requêtes recueillies et transmises à l'usage de générations de prêtres est l'“ Almanach de requêtes du Maître Chisong ". Cet Almanach nous donne une vue panoramique de la pratique rituelle, des conditions matérielles et des croyances religieuses de la société médiévale chinoise. Véritable livre de prières, l'ouvrage plonge le lecteur dans l'intimité des paroles prononcées au cours de rituels historiques, où le fidèle expose ses souffrances et ses détresses aux dieux. Les thèmes des requêtes vont du plus ordinaire au plus poignant : contrariétés domestiques, sortilèges et malédictions, invasion des champs par des rats et des sauterelles, sécheresse, brigands, incendie, guerre, accouchement, maladies, obsèques, salut des défunts. Le taoïsme développe son rituel de présentation de requêtes, " remède salutaire pour l'humanité », dans le même temps où les rites bouddhiques pour le rachat des morts gagnent du terrain en Chine. La conception bouddhique de la transmigration se trouve en conflit avec le culte aux ancêtres et les croyances chinoises relatives au destin des défunts. II en résulte, selon la thèse de cet article, un désaccord évident entre pratiques rituelles et théories traditionnelles tant dans les textes liturgiques que dans les documents funéraires fournis par l'archéologie.

\section{Citer ce document / Cite this document :}

Verellen Franciscus. The Heavenly Master Liturgical Agenda According to Chisong zi's Petition Almanac. In: Cahiers d'Extrême-Asie, vol. 14, 2004. In Memoriam <name ref = "persee-web:/authority/164296">Isabelle Robinet</name> (19322000). Pensée taoïste, Alchimie et cosmologie. pp. 291-343;

doi : https://doi.org/10.3406/asie.2004.1211

https://www.persee.fr/doc/asie_0766-1177_2004_num_14_1_1211

Fichier pdf généré le 06/02/2019 


\title{
THE HEAVENLY MASTER LITURGICAL AGENDA ACCORDING TO CHISONG ZI'S PETITION ALMANAC
}

\author{
Franciscus VERELLEN
}

\begin{abstract}
La tradition liturgique examinée dans cet article émane de la communauté dite des Maîtres célestes, première organisation ecclésiastique du taoïsme, qui perdure depuis le deuxième siècle apr. J.-C. jusqu'à nos jours. Au cour du programme liturgique circonstancié de la communauté primitive, le rituel de présentation de requétes est un modèle adaptable à tous les besoins. Le manuel normatif de requêtes recueillies et transmises à l'usage de générations de prêtres est l'" Almanach de requêtes du Maître Chisong ». Cet Almanach nous donne une vue panoramique de la pratique rituelle, des conditions matérielles et des croyances religieuses de la société médiévale chinoise. Véritable livre de prières, l'ouvrage plonge le lecteur dans l'intimité des paroles prononcées au cours de rituels historiques, où le fidèle expose ses souffrances et ses détresses aux dieux. Les thèmes des requêtes vont du plus ordinaire au plus poignant : contrariétés domestiques, sortilèges et malédictions, invasion des champs par des rats et des sauterelles, sécheresse, brigands, incendie, guerre, accouchement, maladies, obsèques, salut des défunts. Le taoïsme développe son rituel de présentation de requêtes, "remède salutaire pour l'humanité », dans le même temps où les rites bouddhiques pour le rachat des morts gagnent du terrain en Chine. La conception bouddhique de la transmigration se trouve en conflit avec le culte aux ancêtres et les croyances chinoises relatives au destin des défunts. Il en résulte, selon la thèse de cet article, un désaccord évident entre pratiques rituelles et théories traditionnelles tant dans les textes liturgiques que dans les documents funéraires fournis par l'archéologie.
\end{abstract}

The liturgy of early Heavenly Master Taoism 天師道 was based on the ritual presentation of petitions, called shangzhang 上章 or zouzhang 奏章. The petition ritual constituted a paradigm that could be adapted to any number of specific needs or circumstances by varying the content of the petition presented. Thus the scope of the Heavenly Master ritual program can be gauged by identifying the issues addressed in its petitions. In the Chisong zi zbangli 赤松子章曆, the Petition Almanac of Master Red Pine, we are fortunate to possess a normative manual of petition models that were collected and transmitted for use by

Cabiers d'Extrême-Asie 14 (2004) : 291-343. 
generations of priests.' A product of centuries of accretion, this manual provides firsthand evidence of the methods and objectives of Heavenly Master liturgical practice as it evolved between the Eastern Han (AD 25-220) and the Tang (618-907) periods.

Master Red Pine's petition almanac is in fact a book of prayers in which the medieval worshipper lays his afflictions and anxieties before the gods. Although his, or her, voice is heard through the intermediary of a priest, in ritual language that is by nature formulaic, it speaks to us with a stark immediacy. The petitions, whose words were pronounced in historical rituals, reflect the material conditions of the society that produced them. Their themes range from the poignant to everyday concerns: funerary and mortuary rites, disease, drought and pests, spells and curses, public safety, domestic life. The officiating priest, providing a rationale for the sufferings brought before him and for the remedies proposed, in addition offers significant insights into the world view and theology within which the ritual functioned.

I have separately described the production of liturgical petitions and the petition ritual itself. ${ }^{2}$ Here I shall limit my introductory remarks to an outline of the ritual's essential features and some structural characteristics of the petition documents, including their use of formulaic modules. After a brief review of the belief system underlying the Heavenly Master petition ritual, I will let the texts speak for themselves. For the purpose of analysis, I have divided a representative sample, comprising about half of the book's contents, according to the communal entities to which the petitions relate. Across these, some specific target groups can be discerned, for example in the feminine concerns and deities in the petitions on childbirth or sericulture. Within such social distinctions, the petitions are further grouped by themes. In conclusion, some tentative observations are offered on the relation between healing and redemption in the Heavenly Master tradition, based on the evidence of liturgical petitions and tomb documents recovered by archaeology.

1 DZ 615. Another major compilation is the Taishang xuanci zhubua zhang 太上宣慈 助化章, DZ 617, by Du Guangting 杜光庭 (850-933). It also contains early materials that can be usefully consulted alongside the Chisong zi zhangli. Works in the Zhengtong Daozang 正統道藏 (DZ) are numbered according to The Taoist Canon: $A$ bistorical companion to the Daozang, eds. K. Schipper and F. Verellen, forthcoming, Chicago: The University of Chicago Press, 2004. The present study was generously supported by the Research Grants Council of Hong Kong. The author is indebted to Monica Esposito and Phyllis Brooks for valuable improvements of the manuscript.

2 See Fu Feilan 傅飛嵐 (Franciscus Verellen), “Tianshi dao shangzhang keyi: Chisong zi zhangli he Yuanchen zhangjiao licheng li yanjiu 大師道上辛科儀一『赤松了章曆』和『元辰 章醮立成曆』研究," in Daojiao jingdian yu Zhongguo zongjiao wenbua 道教經典與中國宗教文 化, ed. Lai Chi Tim 黎志添, Hong Kong: Zhonghua shuju, 2003, pp. 37-71. 


\section{Master Red Pine's Almanac}

The introduction to the Chisong zi zhangli places the book's historical origin at the beginning of the Heavenly Master community itself: under the Han (206 BC-AD 220), it relates, men and demons mingled promiscuously and miasmas spread through the land. ${ }^{3}$ In his mercy, Lord Lao descended to Mount Crane Call, Heming shan 鶴鳴山, ${ }^{4}$ and bestowed a set of holy scriptures on Zhang Daoling 張 道陵, the first Heavenly Master, as a saving remedy for mankind. The texts revealed included the Orthodox One Covenant 正一盟威, ${ }^{5}$ the Protocol of the Twelve Hundred Officials 千二百官儀, ${ }^{6}$ as well as Three Hundred Great Petitions 三百大章. Putting into effect Lord Lao's proclamations, Zhang then governed the households and converted the people of the Twenty-four Dioceses 二十四治 by means of fu 符-talismans and the zhang 章 -petitions. ${ }^{7}$ However, the introduction concludes, "Over the long years of subsequent ages, precious petitions fell away and were lost. Those surviving today amount to one or two out of ten."

The petitions transmitted in the Chisong zi zhangli amount to twenty percent of the putative original set of three hundred. The texts do indeed preserve elements of the ancient liturgy of the Hanzhong 漢中 community in secondcentury northern Sichuan, referred to as the "old rites of the Heavenly Master" 天師舊儀. ${ }^{8}$ Anna Seidel suggested the Chisong zi zhangli contained traces of Han

3 Chisong zi zhangli 1.1a. Cf. the fifth-century Santian neijie jing :天内解粩 $1.5 \mathrm{a}$, DZ 1205: "From the reign of Han Guangwu (AD 25-57) onwards, the ways of the world gradually declined and men and demons intermingled."

4 In Yuelai 悦来, Dayi 大色, on the western edge of the Chengdu plain in Sichuan. Heming shan is consequently regarded as the founding site of Heavenly Master Taoism.

5 The terms of the "new covenant" and founding charter of the Heavenly Master church. The story of Laozi's descent and revelations to Zhang Daoling in response to demonic irruptions is told in many Heavenly Master texts, e.g. Lu Xiujing's 陸修靜 (406477) Lu xiansheng daomen kelüe 陸先生道門科略 1a, DZ 1127.

6 Fragments of this ancient manual and its petitions survive in the Zbengyi fawen jing zhangguan pin 正一法文程章官品, DZ 1218, and in Dengzhen yinjue 登真隐訣 3, compiled ca. 500 by Tao Hongjing 陶弘景, DZ 421. See Wang Zongyu 王宗星, “Tóshin inketsu ni mieru tenshidō『登真鿵訣』にみえる天師道, Tōbō shükyō 東方宗教 96 (2000), pp. 19-37, and Ursula-Angelika Cedzich, "Das Ritual der Himmelsmeister im Spiegel früher Quellen: Übersetzung und Untersuchung des liturgischen Materials im dritten chüan des Teng-chen yin-chüeh," Ph. D. dissertation, Würzburg University, 1987.

Cf. Franciscus Verellen, "The Twenty-four Dioceses and Zhang Daoling: The spatio-liturgical organization of early Heavenly Master Taoism," in Pilgrims, patrons, and place: Localizing sanctity in Asian religions, eds. Ph. Granoff and K. Shinohara, Vancouver: University of British Columbia Press, 2003, pp. 15-67.

${ }^{8}$ E.g., Chisong zi zhangli 4.24a. See also the expressions "according to the ancient norm of the Heavenly Master" 依天師鹤式 (4.25b) and “according to the ancient rites" 依 萑儀 (3.4a). The term "ancient rites" is already used in this sense in the third-century Heavenly Master texts Dadao jialing jie 大道家令戒, in Zbengyi fawen tianshi jiaojie kejing 正. 一法文天師教戒科釉 17a, DZ 789, and Shangqing huangshu guodu yi 上清黄書過度儀 $22 \mathrm{~b}$, DZ 1294. 
religion even prior to the rise of Heavenly Master Taoism, and evidence in the present article supports this view. ${ }^{9}$ At the same time, many petitions show the influence of the theological innovations introduced by the fourth-century Shangqing 上清 revelations, masterfully charted by Isabelle Robinet. ${ }^{10}$ The Lingbao 靈 scriptures, Buddhist notions of karmic retribution and transmigration in various degrees of assimilation, even allusions to cults and practices typical of the Tang are also present. ${ }^{11}$ In addition to the "old rites," the Chisong zi zhangli frequently quotes the Taizhen ke 太真科 $\operatorname{code}^{12}$ as well as the "Protocol of the Twelve Hundred Officials," mentioned among the founding revelations.

\section{The manual}

The Cbisong zi zhangli comprises four main components: (1) an inventory of the various petition rituals and of the pledges associated with the presentation of each type of petition; ${ }^{13}$ (2) calendrical indications, i.e. the "almanac" for determining appropriate days for the performance of petition rituals; (3) text models for the different types of petitions; and (4) miscellaneous ritual instructions.

The term "almanac" 曆 features in the titles of several cognate texts. ${ }^{14}$ At the outset, the Chisong zi zhangli refers to an earlier almanac that was likewise ascribed to Master Red Pine, the Cbisong zi li 赤松子暦. Red Pine, Master of Rain 雨師 at the time of the mythical tiller Shennong 神農 and a popular immortal in Han times, ${ }^{15}$ was subsequently revered as the patron of various esoteric methods

"See Anna Seidel, "Traces of Han religion in funeral texts found in tombs," in Dōkyō to shūkyō bunka 道教と宗教文化, ed. Akizuki Kan'ei 秋月觀暎, Tokyo: Hirakawa, 1987 , p. 41 , and mortuary petitions discussed below.

10 In La révélation du Shangqing dans l'bistoire du taoïsme, 2 vols., Paris: École Française d'Extrême-Orient, 1984.

"For example, the city god 城隍 cult (Cbisong zi zbangli $4.11 \mathrm{~b}$ ), the Way of Filial Devotion 䒚道 (4.22b), or the burning of [paper] garments and money for the benefit of the dead (5.24a). Examples of Shangqing influence can be seen in certain citations of the Taizhen code (see below) and the celestial court chosen as addressee for the petitions; of the Lingbao scriptures, in concepts of karmic morality and destiny, as well as elements of Buddhist cosmology.

12 Referring to a Taoist liturgical compendium of the early fifth century that included many statutes pertaining to Heavenly Master ritual as well as the new Shangqing codification beginning in the fourth. See Ōfuchi Ninji 大涇忍爾, Dōkyō to sono kyōten: dökyōshi no kenkyūu, sono 2 道教とその經典—道教里の研究，其の二: Tokyo: Sōbunsha, 1997, pp. 409-505. Fragments of this code survive in numerous quotations and the Taizhen yudi siji mingke jing 太真玉帝四極明科釈, DZ 184.

${ }^{13}$ Chisong zi zhangli 1.2a-17b. This part, titled "Petition pledges" 章信, lists the 134 titles of the petition models that had previously been contained in the collection. Sixtysix of these survive in the present version.

${ }^{14}$ E.g., the Yuanchen zhangiiao licheng li 元辰章醮立成暦 (Six Dynasties), DZ 1288, discussed in my "Tianshi dao shangzhang keyi."

15 See Max Kaltenmark, Le Lie-sien tchouan, Paris: École Française d'Extrême-Orient, 
including Nurturing Vitality 盖生 techniques, medicinal formulas, alchemical procedures, and certain Shangqing meditations. ${ }^{16}$ In the Shangqing pantheon, Chisong zi holds the titles Perfected of the Southern Peak 南获真人 and Perfected of the Great Void 太虚真人. The spiritual lineage of Maoshan identifies him as the disciple of Lord Huang-Lao 黄老君 and master of Lord Pei 裴君, two patron saints of the Shangqing revelations. ${ }^{17}$ Red Pine's link with calendrical divination pertaining to petition rituals is explained in the introduction:

Master Red Pine enquired of the Heavenly Elder Tianlao Pingzhang 天老平長

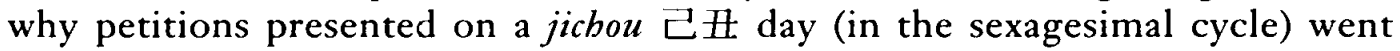
unanswered. ${ }^{18}$ Pingzhang replied: "When the petition and reverent offerings arrive at the Gate of Heaven 天門, the gate is closed." Again [Red Pine] asked at what times of the day and the night [the gate] opened and closed. Pingzhang gave a detailed reply in accordance with the written codes... ${ }^{19}$

1987, pp. 35-42. On Chisong zi's association with macrobiotic hygiene practices from the third century B.C. onwards, see Donald Harper, Early Chinese medical literature: The Mawangdui medical manuscripts, London: Kegan Paul, 1997, pp. 114-117.

${ }^{16}$ For example the meditation on the Nine Perfected 九真. See Shangqing taishang dijun jiuzben zhongjing 上清太上帝君九真中經, DZ 1376. In addition to the Chisong $z i$ zhangli, other Six Dynasties texts ascribed to the immortal in the Taoist canon are the Shangqing jiuzhen zhongjing neijue 上清九真中經内訣, DZ 908 (on alchemical methods) and the “Chisong zi zhouhou yaojue 赤松子肘後樂訣," in Taiqing jing tiansbi koujue 太清經 天師口訣 4b-15b, DZ 883 (medical recipes). See also the Tang compilations Taishang feibu nandou taiwei yujing 太上飛歩南斗太微尤經, DZ 638 (on meditation), Dongxuan lingbao daoxue keyi 洞玄露䆩道學科儀, DZ 1126 (precepts for religious communities, including taboo and calendrical observations), and Taiqing daoyin yangsheng jing 太清導引 養生經, DZ 818 (selected gymnastic exercises). The tenth-century Cbisong zi zhongjie jing 赤松了.中誠經, DZ 185, ascribes certain miraculous cures, effected through retributive morality, to the immortal.

17 See Dongxuan lingbao zhenling weiye tu 洞玄露貿真露位業圖, 3a, DZ 167, originally compiled ca. 500 by Tao Hongiing 陶弘景. Cf. Tao's commentary in Zhen'gao 真誥 (499) 5.1 a, DZ 1016, where Lord Pei refers to Chisong zi as his teacher. According to Zben'gao 14.19a, Red Pine's multiple titles belong to his different hypostases: "Chisong zi" at the Southern Peak, "Great Void Perfected" in the Great Void, and several others.

18 Tianlao is a conflation of the counselor of the Yellow Emperor tradition (Warring States) with an incarnation of Laozi deified (Han). See Zhu Yueli 朱越利, “Tianlao kao 天 老考," Zongjiao xue yanjiu 宗教學研究 1986.2, pp. 52-58. The Heavenly Elder was also the middle star of the Santai 三台 constellation. See Han shi waizbuan 韓詩外傅 by Han Ying 韓嬰 (fl. 150 B.C.), Han shi waizhuan jishi 韓詩外傳集釋 edition by Xu Weiyu 許維透, 8.277, Peking: Zhonghua shuju, 1980. Several late Tang and Song sources elaborate on traditions associating Tianlao with celestial divination, e.g. Tianlao shenguang jing 天老神 光經, DZ 866, and Xuanyuan benji 軒轅本紀, quoted in Yunji qiqian $100.10 \mathrm{~b}$ and passim. The appellation Pingzhang is not explained by Zhu Yueli ("Tianlao kao," 57) and remains a mystery.

${ }_{19}$ Chisong zi zhangli 1.1a-b. On the Gate of Heaven as destination of the petitions, see below. A table of opening hours, "Tianmen kaishi 天門開時," is provided in Chisong $z i$ zhangli $1.19 \mathrm{a}-\mathrm{b}$, followed by a table of closing hours, “Tianmen bishi 天門閉時" $(1.19 \mathrm{~b}-$ 
The almanac, therefore, was indispensable for the performance of petition rituals. In the version that has come down to us, it is set out in discontinuous fashion, occupying most of the sections $1.19 \mathrm{a}-26 \mathrm{~b}$ and $2.1 \mathrm{a}-23 \mathrm{~b}$. The various parts of the petition almanac combine ritual concerns, such as taboo avoidance, with calendrical indications and divinatory functions. The Six Jia 六甲 deities, spirits of the sexagesimal cycle presiding over each of the six periods of ten days beginning with the heavenly stem jia, were invoked for protection or healing when passing through critical junctures. ${ }^{20}$ Taking in addition the festival days of the liturgical year into account, ${ }^{21}$ the opening hours of the Gate of Heaven, and considerations particular to the case, the almanac allowed the priest to select auspicious or admissible days for the presentation of petitions. ${ }^{22}$ This preoccupation with calendrical considerations is deeply rooted in the Chinese practice of consulting day books 日書 before undertaking ritual activities of any kind. ${ }^{23}$

Taken together, the different parts of Red Pine's manual for practitioners allow us to reconstruct the social context of the petition ritual, from both the priest's and the lay follower's perspectives: First, a member of the congregation, the client, approaches the priest with a problem to be resolved. The priest would be the occupant of a diocesan office 治職 and a ranking initiate holding Heavenly Master or Shangqing ordination registers. ${ }^{2+}$ The client approaches this notable's sanctuary with due respect:

20a). See also the related narrative “Tianlao wen sanhuang 大老䦓 皇” (2.27b-28a) where the I Ieavenly Elder learns from the Three Sovereigns (Fuxi, Shennong, and Huangdi) the use of the wuxu 戊戍 talisman: on wuxu days the Emperor of Heaven 天帝 (the brightest of the five stars of the celestial north pole and an important deity in Han funerary documents) set forth from the Gate of Heaven and granted wishes to those employing the corresponding talisman of that day.

20) See the paragraph describing their visualization, “Liujia cunsi 公用保䍐," Chisong $z i$ zhangli 2.16a. On the liujia gods, see Inoue Yutaka 井上半, “Rikutei, rikukōshin no

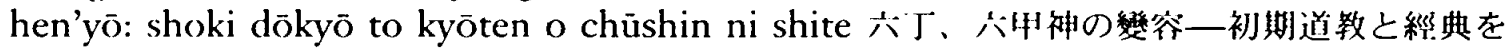
中心にして, Tōbō shükyō 来方宗教 80 (1992), pp. 15-32.

21 Especially the five la $\mathrm{ti}$ 腦, three yuan : Stein, "Religious Taoism and popular religion from the second to the seventh centuries," in Facets of Taoism, eds. H. Welch and A. Seidel, New Haven: Yale University Press, 1979, pp. 69-72. On the la-festivals, see also Derk Bodde, Festivals in classical China: New Year and other annual observances during the Han dynasty, 206 B.C.-A.D. 220, Princeton: Princeton University Press, 1975, pp. 49-74.

"2 See Marc Kalinowski, "La littérature divinatoire dans le Daozang," Cabiers d'Lixtrême-Asie 5 (1990), pp. 96-99.

${ }^{23}$ On the early use of day books in Chinese ritual, see Michael Loewe, "The almanacs (jib-sbu) from Shui-hu-ti: a preliminary survey," Asia Major 3rd ser. 1.2 (1988), pp. 1-28, and Poo Mu-chou, In search of personal welfare: a view of ancient Chinese religion, ch. 4, Albany: State University of New York Press, 1998.

${ }^{2+}$ One petition indicates the title of libationer 祭酒 of Yangping Diocese 陽平治, the highest-ranking priest after the Heavenly Master himself (Cbisong zi zbangli 2.22b). Another has the highest Shangqing liturgical degree, disciple of the Three Luminaries from the Great Cavern of Highest Purity 上清大洞 : 景弟子 (Chisong zi zhangli 4.23b). 
All that enter the [sanctuary of a] diocese must be serious and reverential. Their deportment must not be proud or extravagant. Those who enter a diocese must not give themselves censorious airs, speak vainly or inappropriately, nor chatter or jest. Within the diocese it is forbidden to expose one's body [...]. Those who visit a diocese to request a petition to be saved from the tribulations of disease are required to be girded and wear clogs 履版. They should kowtow with reverence and make a full confession. They must not be haughty or malicious, nor brashly extol themselves. Offenders incur a third-degree punishment :

The priest takes down the client's “deposition” of the petition issue 章解, which is presented either in writing or orally. The client's complete name, date of birth, and place of residence are recorded with great care, as well as the officiating priest's affiliation, liturgical rank, and other particulars. The pervasive Heavenly Master concern with registration is in evidence here. This is because the resolution of the problem is essentially envisaged as an emendation of the registries of destiny. The smallest mistake would undermine the whole enterprise and could lead to unforeseeable consequences. Next, the priest selects the appropriate category of petition ritual on the basis of the inventory. Beside the selected entry, he finds the list of corresponding pledge offerings. He communicates this information to the client, who is to prepare the listed items for presentation during the ritual. The pledges consist of set quantities of rice, oil, silk, mats, writing brushes, ink, paper, silver or gold rings, incense, cash, and fruit. A special category comprises “substitute figurines" 代形, effigies made of gold, silver, or pewter (see bclow). The plcdgcs are presented as tokens of sincerity and as redemptive payments. ${ }^{26}$ Then an appropriate date for the ritual is determined with the help of the almanac. Finally, the priest searches the main body of the manual for a suitable model petition, perhaps using the inventory as an index. He transcribes this model text, inserting variable elements in the place of the words moumou 某某, XYZ or such-and-such, from the client's petition statement and observing strict rules on the ritual handling of brush, ink stone, and paper, as well as appropriate calligraphic styles and the layout of the document. The petition models generally name the appropriate deities to be invoked to deal with specific issues, but the priest may also need to adjust these to fit the case. For this, the "Protocol of the Twelve Hundred Officials" was at hand, the ancient manual mentioned above. It provided an inventory of the divine bureaucracy with the names of the lords presiding over each office, their residences, and their subordinate staff. The names were classified according to similar categories of afflictions or crises as the petition rituals themselves and could be transcribed into corresponding litanies in the

${ }^{25}$ Chisong zi zhangli $2.28 \mathrm{~b}-29 \mathrm{a}$. The punishment for a third-degree conviction is not indicated (cf. the list of sanctions in 2.19a).

26 The subsequent disposal of the pledges was also strictly regulated, allotting not more than the third part to the master, the remainder being destined for charity. For details, see Verellen, "Tianshi dao shangzhang keyi," pp. 41-43. Shi Zhouren 施舟人 (Kristofer Schipper), “Daojiao de qingyue 道教的清約," in Faguo banxue 法國漢學, vol. 7, Peking: Zhonghua shuju, 2002, pp. 149-167, discusses the economic implications of the pledge system for the clergy. 
petition text. In many cases, the pantheon invoked in Red Pine's petition almanac can still be traced to surviving fragments from the protocol. ${ }^{27}$

The presentation of the petition is embedded in an audience ritual 朝禮, where the priest assumes the role of a courtier petitioning the ruler through the presentation of a formal document. The priest enters the altar area uttering incantations addressed to the four directions of space. ${ }^{28}$ This is followed by the opening rite of "activating the incense burner" 發爐. The way the smoke rises from the burner portends the success of the petition. Like the activation of the incense burner, the subsequent “exteriorization of the officials" 出官 is a visualization exercise in which the priest invokes his personal, interior pantheon. Besides “merit officers" 功曹, he summons mounted messengers and subaltern officials and clerks to convey the petition to the celestial court. At this point in the liturgy the reading of the petition takes place, followed by the ritual sealing of the document. The envelope is inscribed with the words "Respectfully submitted to the Jade Throne of the Gold Portal of Void Spontaneity" 虚无自然金關玉陛下, the address of the court of the Shangqing Latter-Day Saint 後聖 Li Hongyuan 李弘 元. ${ }^{29}$ Now the petition is ready to be conveyed to heaven. The audience in heaven is carried out in the priest's mental eye: he prostrates himself before the altar and visualizes a surge of red qi-energy emerging from his heart and rushing up to heaven. The ecliptic 黄道 of the sun comes into view. ${ }^{30}$ Traversing it, he perceives the Gate of Heaven among auspicious purple clouds. $\mathrm{He}$ is admitted to the palace, where he first pays his respects to the Heavenly Master Zhang Daoling. An immortal emerges to receive the petition memorial. Finally, the priest is led into the presence of the Most High who glances through the petition and issues the endorsement "Jade Throne of the Highest Clarity" 太清玉陛下. The priest then pays his respects and returns to the altar. Rising, he announces: "I beg to report" 以聞. ${ }^{31}$ The ritual ends with a series of closing rites that symmetrically retrace the opening steps: return of the officers, their dismissal and recompense, closing of the incense burner, and finally exit from the altar area.

27 Especially those preserved in Zhengyi fawen jing zhangguan pin. Numerous examples of the relationship between the two manuals are documented below.

28 On the altar and petition ritual, see "Tianshi dao shangzhang keyi," pp. 50-54. Cedzich, "Das Ritual der Himmelsmeister," pp. 61-105, contains a reconstruction of the petition ritual from liturgical fragments preserved in Dengzben yinjue. See also Maruyama Hiroshi 丸ulı公", “Sei'itsu dōkyō no jōshō girei ni tsuite iF:一道教の上毫儀禮に ついて,"Tōbō shükyō 来方宗教 68 (1986), pp. 44-64.

2" See his “Annals," Shangqing bousbeng daojun lieji 1:清後垶道䑠列紀 (Eastern Jin [317-420]), DZ 442, partially translated in Michel Strickmann, Le taoisme du Mao Chan: chronique d'une révélation, Paris: Collège de France, 1981, pp. 209-224, and integrally translated in Stephen Bokenkamp, Early Daoist Scriptures, Berkeley: University of California Press, 1997, pp. 339-362.

30 On the term buangdao, see Monica Esposito, "Il 'ritorno alle fonti', costituzione di un dizionario di alchimia interiore dell'epoca Ming e Qing," in Le fonti per lo studio della civilità cinese, ed. Maurizio Scarpari, Venice: Cafoscarina, 1995, pp. 110-113.

31 “Cunsi 存思," Chisong zi zhangli 2.23b-24b. 


\section{The petition document}

Liturgical petitions, like any genre of court communication, followed a closely regulated format. Along with the correct method of redaction, rules also covered locutions of courtly address: "Petitions must invariably carry the words in fear and trepidation 誠惶誠恐; violators suffer diminutions of lifespan." This formula, emulating memorials addressed to the emperor, entered the language of Heavenly Master petitions at an early stage. ${ }^{32}$ Standard opening and closing locutions for written communications were also obligatory in petitions:

The code states: When presenting a petition in cases of minor disease or trifling matters, it suffices to say your servant $X$ knocks bis bead to the ground and respectfully submits 臣某稽首再拝上言 [...]. When presenting a petition in cases of severe disease and urgent matters, state your servant $X$, begging for pardon for bis capital crime, knocks his bead to the ground and respectfully submits 頓首死罪稽首再拝上言. Likewise at the end of the petition. Violators suffer diminutions of lifespan. ${ }^{33}$

At the beginning of each petition, the priest fully states his ordination rank 具法 位, followed by the words "I respectfully announce, in conformity with the documents”上言謹按文書. Though this is not always indicated, the particulars from the client's deposition should come next, with an announcement of the petition issue and a tentative diagnosis as to its causes. A comprehensive statement of contrition covers all conceivable offenses committed by living or dead members of the family that might constitute such causes. The priest's selfdepreciating references to his own human nature and clerical rank merge into the client's confession of having invited the misfortune upon himself:

Your servant $\mathrm{X}$ and his disciples are the descendants of lowly rustics 草苗. Farm work is our livelihood. By a rare good fortune he got to serve the Great Tao. He was bestowed multiple ordination registers 賜佩重籍 and honored with diocesan office 治職. ${ }^{34}$ Celestial officials and soldiers guard his person. [Yet] he has amassed faults like mountains and seas, and not a shred of merit. Accountable to heaven and earth, he dares not rest at ease. ${ }^{35}$

With slight variations, references to the petitioner's profane, carnal nature 肉人 and lowly extraction 下官之餘 are expressed in recurring modules. The standard term is "born from a womb" 胎生: “An ordinary being born from a womb 素以胎 生, I was granted the rare good fortune 千載有幸 to serve the Great Tao 得奉大道. In their compassion, my teachers and elders conferred a diocesan register 治籍 on me." ${ }^{36}$ The officiant's humanity ranks him below the gods and immortals, but also

32 “Chenghuang chengkong 誠惶誠恐," Chisong zi zhangli $2.18 \mathrm{a}$. Cf. the early "personal writ [of confession] to the Three Officials" 三官手書 preserved in Taishang xuanci zbubua zhang 2.12a and ritual instructions from Dengzhen yinjue, cited in Yunji qiqian 雲篖七銥 (ca. 1028) 45.13a, DZ 1032.

33 “Qishou zaibai 稽首再择” and “Dunshou sizui qishou zaibai 頓首死罪稽首再拝," Chisong zi zbangli 2.18a-b. On qishou as a ritual act, cf. Dengzben yinjue in Yunji qiqian 45.13a.

34 See Lu xiansheng daomen kelüe 5b-6a.

${ }^{35}$ Chisong zi zhangli $3.5 \mathrm{~b}-6 \mathrm{a}$.

${ }^{36}$ I.e., ordination (cf. Lu xiansheng daomen kelüe 7a). Chisong zi zhangli $4.23 \mathrm{~b}$. 
sets him off from demonic beings. These extra-human categories are "born by transformation" 化生. ${ }^{37}$ The Buddhist fourfold classification of creatures 四生 distinguishes birth from egg, womb, moisture, and spontaneous transformation. ${ }^{38}$

At times the voices of the petitioning priest and lay patron blend together, the former impersonating the latter:

Full ordination rank. I [priest] respectfully submit, in conformity with the documents. Born on such-and-such day and month of the year such-and-such, in such-and-such prefecture, county, and village, this day [the client?] states and personally declares: A man of flesh born from a womb 胎素肉人 and descended from mortals 枯骨子孫, he was granted the rare good fortune to serve the Great Tao. Ever graciously favored, boundless is his exultation. Yet being a man of flesh, numerous are his failings in the faith 信向多違. Thus he has invited harm and incurred manifold adversities. Suffering delusive thoughts and dreams, he has ungodly visions... ${ }^{39}$

At this juncture, however, the roles reemerge clearly with the priest stating his liturgical office ("X has approached your servant, requesting this petition") and enumerating the faith pledges provided by the client. Having thus assured the gods of the petitioner's penitence and largesse, the priest can then initiate the denouement. This takes the form of the Invitation of Officials 請官, an invocation of deities apt to resolve the petition issue. It can be coupled with a commitment to see to their recompense upon achieving the desired result:

The heavenly officials invited are to be promoted and rewarded in accordance with the Three Assemblies Announcement of Merit 三曾言功. 'This pledge shall be honored without fail 不負效信. May the Most High in his mercy resolve the matter, et cetera 恩惟太上分別云云. ${ }^{40}$

China's earliest known writings, the oracle bone inscriptions from the late Shang period (ca. 1200-1045 B.C.), were reverently hoarded as divination records and in time buried. They were then forgotten, to be rediscovered in the early twentieth century. Many of the oracle queries concerned the same issues as the petitions discussed below: drought, locusts and other pests, war, communication with spirits and demons, disease, dreams, childbirth, and so on. ${ }^{41}$ Moreover, the same fundamental cosmological and spatio-calendrical categories

37 See Nüqing guilü 女青鬼律 5.1b-2a, DZ 790, where barbarian demons are classified this way. In Master Red Pine's almanac, the term buasbeng is sometimes used for "transcendence." In the Petition on Sending the Clothes and Effects of the Deceased discussed below, however, it means "reincarnation."

38 See for example the classification in Yuqie shidi lun 揄伽師地論 2.288a, T. 30, no. 1579, a Tang translation of the fourth-century Yogācāra-bhümi-siastra.

39 Chisong zi zhangli $5.15 \mathrm{a}-\mathrm{b}$.

40 Chisong zi zhangli $3.21 \mathrm{~b}$. Cf. the variant "this loyal oath shall not be broken 不負丹 誓” (5.34a), a formula also found in Shangqing huangsbu guodu yi 4a.

+1 See the classification in Fiagu wen heji 甲骨文合集, ed. Guo Moruo 郭沫若 (18921978), Peking: Zhonghua shuju, 1982, and its supplement fiagu wen beji bubian 甲骨文合 集補編, ed. Peng Bangjiong 彭邦坸 et al., Peking: Yuwen chuban she, 1999. 
(cardinal directions, sexagesimal cycle) that underlie Master Red Pine's almanac also oriented oracle bone divination in time and space. ${ }^{42}$ Although the petition texts only tangentially concern divination, they too were solemnly preserved as records of ritual events and eventually offered in sacrifice:

Those petitions that were not burnt [as part of the petition ritual] have been kept under seal and shelved in boxes. The scrolls and bundles have accumulated in great numbers. In accordance with the rites, they must not be dispersed. It is feared that there will be losses due to desecration by insects or rats or damage from humidity and decay. Ever reverential, we dare not contravene the guidelines. This day, in accordance with the code, we therefore discontinue and sacrifice so-and-so many pieces collected since such-and-such year, month, and day, transforming them by fire upon such-and-such pure altar/pure place. May the smoke rise up to the gods and cause their qi-energy to descend in turn, spreading good fortune and driving away calamity. ${ }^{+3}$

We also learn that "every petition is based on a standard version 正本. Under no conditions may old copies 故本 be [re]used for transcription, collation, or layout: the circumstances of the cases are not the same, and the officials to be invoked are different." "This, then, is the rationale for Master Red Pine's Petition Almanac: to preserve and transmit "standard versions," from which particulars such as names and places had been removed, for transcription and adaptation to new petition rituals down the centuries.

\section{Some underlying assumptions}

To read the petitions in their religious context, it may be useful to sketch the outlines of the belief system that informed the petition ritual. The metaphoric framework of the court audience is fleshed out with a departmentalized otherworldly administration and judiciary. The "officials" of that administration constitute a pantheon of specialized deities that can be selectively marshaled to examine and resolve the client's ills, and to counter the equally ramified legions of demons perpetrating baleful effects. The bureaucratic logic of this belief system is one of the abiding features of Chinese religion since at least Shang times. ${ }^{+5}$

Under the dispensation of the Heavenly Master, a pantheon of Three Heavens, comprising deities that were bound by the Orthodox One Covenant to a mutually beneficent relationship with the Heavenly Master congregation,

42 See David N. Keightley, The ancestral landscape: Time, space, and community in late Shang Cbina (ca. 1200-1045 B.C.), Berkeley: Institute of East Asian Studies, 2000. The almanac of course also features later developments from various sources (Han cosmology, Buddhism, apotropaic rituals).

43 “Duanzhang 断章," Chisong zi zhangli 2.26b-27b.

44 “Zangzhang guben 藏章故本,” Chisong zi zhangli 2.26a-b. For details, see Verellen, "Tianshi dao shangzhang keyi," pp. 59-60.

45 See David N. Keightley, "The religious commitment: Shang theology and the genesis of Chinese political culture," History of Religions 17 (1978), pp. 214-216. 
superseded the demonic Six Heavens of the preceding age. ${ }^{46}$ The Invitation of the Officials in Red Pine's manual names the lords, officials, and generals that should be summoned for different petition rituals. Each entry describes a situation in which the deity should be invoked. The predicaments include disease symptoms, demon-induced misfortunes, and unfavorable astrological conjunctions. ${ }^{47}$

Another threefold structure divided the world into Heaven 天, Earth 地, and the Water Bureau 水府. These were the realms of the Three Officials 三官, the afterlife judges. According to an early historical record, Heavenly Master petitions were originally confessions addressed to these deities. ${ }^{48}$ In Master Red Pine's almanac, the newly deceased are detained and appear before the Three Officials. ${ }^{49}$ This austere netherworld cosmology is subsequently adorned with the Dantesque Shangqing visions and elaborate hell systems borrowed from Buddhism. Thus the world of the dead is variously named and located: the Six Palaces 六宮 of Fengdu 数都, the Nine Realms of Darkness 九幽, the residence of the Long Night 長夜之府, and the Taiyin palace 太陰宮 in the extreme north, a purgatory where the souls of the dead undergo "refinement" 鋉. $^{50}$ Once the Three Officials have passed sentence, a penitentiary system metes out tortures in numerous "earth prisons" 地獄, including the twenty-four prisons of Mount Tai 泰山二十四狺, the twenty-four prisons of Fengdu, the earth prisons of each of the five Sacred Peaks, and many others. In addition to earth prisons, we also find "heaven prisons 天獄" in the five directions of space. ${ }^{51}$ Afterlife inquisition, like the judiciary of this world, moves along paths of bewildering intricacy. This is in itself a source of anxiety that petition rituals seek to address:

Incarcerated in the sundry prisons, now he is in the Hebo 河伯 prison, now in the Nüqing 女青 prison, now in the temples of the city or soil gods 城隍社廟. Unable to localize the bun 魂 and po 魄 souls of the deceased, we pray that they be transferred 遷達, so that they may peacefully ascend and be clothed and fed in the

th See Santian neijie jing 1.5b-6a.

47 “Qingguan 靖官," Chisong zi zbangli 2.18b-22a. See the translation of the opening paragraph under the heading "Disease" below. Here and below, translated section headings and titles of petitions in the Chisong zi zbangli are rendered in italics.

${ }^{48}$ See the early third-century Dianliue 典略, quoted by the commentator Pei Songzhi 裴松之 (372-451) in Sanguo zhi 漍志 8.264, Zhonghua shuju edition. On the Three Officials, see Lai Chi Tim 黎志添, “Tian di shui sanguan xinyang yu zaoqi tianshi dao

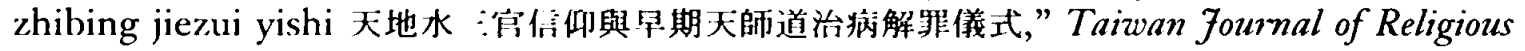
Studies 2 (2002), pp. 1-30.

49) Chisong zi zhangli 6.1a, 17a, and below.

50 For the Shangqing underworld, see Robinet, La révélation du Shangqing, pp. 137138. Kobayashi Masayoshi 小林怪美 regards the infernal Six Palaces as the inspiration for the Six Heavens demonology; see Rikuchō dōkyosshi kenkyū 枀朝道教史研究, Tokyo: Sōbunsha, 1990, pp. 498-506. For Taiyin, see Laozi xiang'er zhu 老子想爾注, 1l. 227-229, 516-517, Dunhuang manuscript S. 6825, reproduced in Ofuchi Ninji 大淵忍爾, Tonko dōkyō 敦煌道稆: Zuroku ben 圆錄編, Tokyo: Fukutake shoten, 1979, pp. 420-434; Cbisong zi zhangli $4.20 \mathrm{~b}$ and below.

${ }^{51}$ See references below and Chisong zi zhangli 3.23a-24a. 
Hall of Heaven 天堂, where they shall wander free and easy 逍遥. ${ }^{52}$

Paradise too has various designations. Beside Hall of Heaven, we find Hall of Blessings 福堂, Court of Blessings 福庭, and others. It is a place of unfettered roaming and beatific rejoicing, where nothing is wanting, and food and clothing are dispensed spontaneously 衣食自然. The vocabulary thus far exactly mirrors Buddhist writings. ${ }^{53}$ Taoists, however, characteristically looked to these Elysian halls as places where the dead could no longer pursue miasmal lawsuits 不得注 訟. ${ }^{54}$ Paradise was attained by transfer or promotion, on condition that the subject had obtained release from prison with full acquittal. Here the petition ritual, the prayers of the apprehensive family, and not least their offerings played their role as a last resort for swaying the prison authorities to "wipe out the charges leveled against the deceased, annul his condemnations, and set him free from prison, his sentence fully served." 55

Despite the imposing address on the petition envelope, the document inside generally appealed to the "Department of Heaven" 天曹. This organization had long been regarded as a place where sins and merits were recorded. ${ }^{56}$ Taishan also frequently appears in the role of registrar. Before becoming a prison complex, the sacred mountain in Shandong, together with nearby Haoli 蓠里, had been associated with death summonses, registration, and judgment. Archaic beliefs concerning life and death registers were, here again, processed through the evolving Shangqing and Lingbao cosmologies. An early Lingbao scripture informs us that each of the Three Officials' realms had multiple palaces, residences, and bureaus, all of which maintained registers of sins and merits. The names of those destined for the Long Night were inscribed in the

52 Chisong zi zhangli $4.17 \mathrm{~b}$. In the three-tiered system of Mt. Fengdu, Hebo and Nüqing were two of the eight prisons beneath the mountain. The city and soil gods performed judicial functions of the local magistrate in the netherworld.

53 See the fifth-century apocryphal "Sutra on Repaying the Kindness by Making Offerings," Fuoshuo baoen fengpen jing 佛説報恩奉盆經 780a, T. 16, no. 686: “Upon obtaining escape from the Three Destinies, they are presently delivered and provided clothing and food spontaneously 得出三塗, 應時解脱, 衣食自然” Each of these terms occurs in the petitions cited below. The significance of the provision of clothing and food in connection with filial offerings to ancestors is discussed in Alan Cole, Mothers and sons in Chinese Buddhism, Stanford: Stanford University Press, 1998, pp. 80-88. Cole's study makes an interesting point about the reversal of parent/child roles in the feeding of ancestors after death, which could be extended to the conception of paradise as a scene of carefree childhood.

${ }^{54}$ See Chisong zi zhangli $6.2 \mathrm{~b}$ and below.

ss See Chisong zi zhangli 6.14a and below. For a comprehensive survey of Buddhist and Taoist hells and paradises in this period, see Xiao Dengfu 萧登福, Han Wei Liucbao fo dao liangjiao zhi tiantang diyu shuo 漢魏六朝佛道兩教之天堂地獄説, Taipei: Xuesheng shuju, 1989.

${ }^{56}$ See e.g. Laozi Xiang'er zhu, ll. 327-328, 372-373. See also Ziyang zhenren neizhuan 紫陽真人内傳 (Six Dynasties) 1.5b-6a, DZ 303, and Dengzben yinjue 3.14a. 
black ledger 黒簿. ${ }^{57}$ A Heavenly Master polemic asserted that this dreaded ledger was kept by the Buddha Sākyamuni, as the lord of death, whereas Laozi attended to the book of life. ${ }^{58}$ The stated aim of the majority of the petitions is to induce otherworldly officials to modify damning register entries to the patron's advantage. To this end, the pledge offerings included ample supplies of writing and correction utensils. A bold strategy consisted in dispatching substitutes to the administrations of the five directions of space to "trade names and exchange bodies 貿名易形” with the petitioner, i.e. replace him in the registers of doom worldwide. ${ }^{59}$

The agents of doom also feature profusely in Master Red Pine's petitions. For further particulars, the petition writer could turn to the "Demon Statutes of Nüqing and the Dark Metropolis” 女青玄都鬼律令, a manual tentatively dated to the third century, but rooted in a long tradition of Chinese demonology ${ }^{60}$ Nüqing and Dark Metropolis were two prisons in the lowest tier of Fengdu. The "Statutes," though transmitted in incomplete form, describe many, and name more than three hundred, of the 36,000 existing demons with a view to enabling adepts to expel them by reciting their names and recognizing them. ${ }^{61}$ Although definitions of “demon" 鬼 are manifold and fluid, as well as relationally conditioned (X's ancestor is Y's demon), a class frequently held responsible for the ills of petitioners is that of perversions of "vital energy" 氣. These are the stale emanations 故氣 of the dead, also known as malignant exhalations 邪氣. Death bringers 繁 and cadavers $\rightleftharpoons$ are related categories of demons. Another kind comprises the essences 精 of natural features (rivers, plants, animals) and objects (stones, dead trees). The most pervasive baleful influence is called "miasma," $z b u$ 注, a notion that is also current in the traditional literature of Chinese medicine and epidemiology. ${ }^{62}$ It is akin to $z b u$ F:, meaning infectious, chronic disease, and also related to the idea of contagion 染疾, but refers to noxious emanations of all sorts, ranging from putrescent organic matter to inauspicious astrological conjunctions that pollute the atmosphere. The word $z b u$ appears in many compounds, such as yangzbu 殊注 (disastrous miasma), sizhu 死注 (deadly or death miasma), shizhu 户注 (corpse miasma), shangzbu 傷注 (deleterious miasma), zbuqi 注氣 (miasmal exhalation),

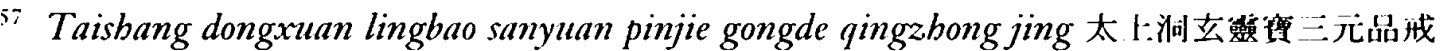
功徳輕重經. (ca. 400), 7a-b, DZ 456.

s8 Santian neijie jing $1.9 \mathrm{~b}$.

59 On this procedure, see the Gold and Purple Effigy Petition below and Yuanchen zhangjiao licheng li $2.4 \mathrm{a}$.

61) On this tradition, see Donald Harper, "A Chinese demonology of the third century B.C.," Harvard Fournal of Asiatic Studies 45 (1985), pp. 459-498. The long title of the work is found in Niiqing guilii 3.1 a.

"For Nüqing and Xuandu, see Taizben yudi siji mingke jing 1.6a-b. A succinct summary of the compilation's unruly contents is found in Michel Strickmann, Chinese magical medicine, ed. Bernard Faure, Stanford: Stanford University Press, 2002, pp. 80-88.

62 Strickmann, Chinese magical medicine, pp. 24-31. 
zhusha 注殺 (miasmal death bringer), and so on. The effects of $z b u$ were correspondingly nebulous, ranging from death and disease to adversity and vexation. They are often encapsulated in the expression kanke 轗軻, denoting the hazardous journey of a carriage along a rutted road. Evoking the vagaries and upsets of life, kanke means straitened circumstances, frustrations, and thwarted hopes; as a psychosomatic condition, the connotations range from exhausted and dispirited to distressed.

Just as human beings dispose of an indwelling pantheon of "officials," they are also subject to the destructive work of parasitic and pathogenic agents ensconced in their bodies. Traditional Chinese belief postulates the cohabitation of multiple psychosomatic spirits in every creature. These comprise seven material po 魄 and three ethereal bun 魂, words translated as “soul” for want of a better equivalent. In Taoist physiological theory, the po-souls are demons that seek the body's destruction. After death, defined as the separation of the souls from the body, the po are commonly said to descend into the earth while the bun rise into the air, a theory that is however often contradicted by the documentary evidence from mortuary rituals. We will return to this question in the conclusion.

In addition to miasma and ritual pollution, violations of precepts, taboo infractions, and inherited guilt also constituted obscure and fearsome threats to the life and wellbeing of the faithful. The Demon Statutes of Nüqing provides precepts for adepts side by side with its laws for demons. ${ }^{63}$ Good moral conduct in effect was an extra weapon in the arsenal against demon infestation. It also preserved the adept from divine retribution in the form of disease and lifespan reductions. The redemption of the dead, with its implications for the welfare of the living, required absolution from transgressions against Buddhist morals as well as Heavenly Master precepts:

We implore pardon for the Three Conditions 三業 and Six Senses 六情 carried over from the deceased's former lives 前身, and in case he accumulated transgressions, or committed cardinal sins, or violated the "Hundred and Eighty Precepts" and was subjected to samsara for ten thousand kalpas 輪回萬劫 in the Long Night of gloom. ${ }^{6+}$

A particular class of petition ritual was designed to improve an individual's personal destiny 本命, defined by the cyclical binomials representing the time of his or her birth, taking into account those of the current year 行年 and other

${ }^{63}$ Nüqing guilii 3.1a-3b. The study by Lai Chi Tim, "The Demon Statutes of Nüqing and the problem of the bureaucratization of the netherworld in early Heavenly Master Taoism," T'oung Pao 88 (2002), pp. 251-281, emphasizes this point.

${ }^{6+}$ Chisong zi zbangli $5.10 \mathrm{~b}$. Three Conditions: Skt. trividba-dvära, three karmic inheritances flowing from deeds, words, and thoughts; Six Senses: a reference to offenses against the "Precepts for Stopping the Six Senses," designed to block the temptations of the eyes, ears, nose, mouth, hand, and heart; the "Hundred and Eighty Precepts" was one of the earliest and most comprehesive sets of rules for Heavenly Master Taoists. See Barbara Hendrischke and Benjamin Penny, "The 180 Precepts Spoken by Lord Lao: A translation and textual study," Taoist Resources 6.2 (1996), pp. 17-29. 
astrological computations. Disease, misfortune, and life cycle crises-the main objects of petition rituals-were considered to be retribution for moral transgressions, infractions of taboos, and "collisions" with baleful stars:

The destiny of every human life stands under the jurisdiction of a constellation. When untoward events occur, one's name is registered in the black ledger, causing a person's spirits to become confused and his sleep restless. Soon he moves with growing difficulty and his lifespan is diminished. But if a gentleman of pure heart and good faith, who places his trust in the law of the Tao, presents his prayers through a petition talisman 章符, his sins are instantly wiped out and blessings come forth to increase his prosperity and long life, while his departed ancestors are transferred, their every wish fulfilled. ${ }^{65}$

\section{THE LITURGICAL AGENDA}

Our sample of petition models from Master Red Pine's almanac is set out below according to the following communal entities: the community at large, the individual as determined by the concept of "personal destiny," the household, and finally the sphere of interaction bridging the living and the dead. Although the petition almanac was probably never organized along such lines-in its present form it shows signs of extensive disarray - the introduction seems to lend some justification to this approach:

Whether a layperson 世人 seeks to present a petition on behalf of home and country 家國, of his or her own person 已身, of dependants 脊㵂, or on behalf of deceased ancestors 先亡, each kind is different according to the particulars. ${ }^{6 t}$

\section{The community}

The petition almanac opens on a semi-official tone. The very first petitions were used in rituals addressing the everyday worries of a rural society, concerned year after year with the vagaries of the weather and the problem of protecting crops against pests. Water management and praying for rain in times of drought were duties incumbent on local officials. In general, the communal rules of the original Heavenly Master congregation in fact made a virtue of shunning contact with state functionaries-and officialdom returned the compliment by referring to the faithful as thieves and bandits. The following texts, by contrast, display the comfortable symbiosis that prevailed at those times when Taoism formed part of the imperial cult.

\section{Farming and sericulture}

The Drought Petition ${ }^{6 /}$ has the trappings of a document of state. Whereas most petition models require the insertion of the locality in minute detail, this

65 Chisong zi zhangli 1.1a-b. For a Heavenly Master destiny ritual, see Verellen, "Tianshi dao shangzhang keyi," p. 39 ff.

"6 Chisong zi zbangli $1.1 \mathrm{~b}$.

67 “Tianhan zhang 天早章,” Chisong zi zhangli 3.1a-3b. 
one refers to the afflicted area as "the territory of the realm." The priest himself assumes the role of the petitioner, acting perhaps on behalf of a local official. Where the officiant usually counts his blessings as a Taoist, here he adds his good fortune of serving the state. The expressions "this sagely age" and "territory of the realm" allude to the current reign.

A humble benighted person, $\mathrm{X}$ happened upon the congregation of the Tao 道會 and was able to witness this sagely age 聖世. Karmic causation 因縁 favored him through induction into the great rites 大法. The Most High granted him broad shelter, while a master took pity upon him. Having not a shred of merit, he fretted morning and night—as if walking on ice or near a ravine 如履冰谷 ${ }^{68}$ 一 that he had no means to repay the kindness of heaven and earth. On the day of his ordination, your servant swore an oath and took it upon himself to reverently serve the school of his master, widely perform the services of a religious, assist the state and uphold life, to work for the salvation of all, and make aiding others his priority. ${ }^{69}$ Of late, heaven and earth are going through ill fortune, yin and yang afflict one another, and the four seasons have lost their measure. The territory of the realm 國境 is suffering severe drought, and cereals are not being harvested. We consider it a surge of demonic disorders 祅災. Pure yang 純陽 is above, condensed yin 凝陰 below. The two $q i$ do not interact, and mysterious (cum imperial) beneficence 玄澤 does not descend. In dry wind and scorching sun, the people endure hardship. Their sowing and reaping having fallen away, they dread the sun like fish in a dry pond 涸魚. ${ }^{70}$

This is followed by a philosophical reflection on the cosmo-political reasons for and wider consequences of drought, and the need to restore the Five Phases. Despite the conventional rhetoric and the official character of the ritual, the speaker squarely places himself in the Heavenly Master liturgical tradition:

Your servant does not venture to make his own determinations, but reverently relies on the rites of the Heavenly Master 天師科法. May he undergo boiling and scalding for his failings! Respectfully he submits this petition, knocking his head to the ground in fear and trepidation, a criminal deserving to die.

The invocation confirms that the petition does indeed derive from the original Heavenly Master manuals: The officials invited correspond, with minor variations, to a section of the pantheon in charge of rain rituals in the "Categories of Petitions and Officials According to the Zhengyi Fawen Canon" 正一法文經章官品. It is probable that the names were ultimately transcribed into the model petition from a corresponding register in the ancient Protocol of the Twelve Hundred Officials: ${ }^{71}$

${ }^{68}$ An allusion to the Book of Poetry, Maoshi 毛詩, “Xiaoya 小雅," 12.420, Shisan jing 十二䜌 edition: "Trembling upon the verge of a ravine, wary as though treading on thin ice” 惴揣小心, 如臨于谷。戰戰競競, 如履薄冰.

69 On ordination oaths, see the transmission ritual by Lu Xiujing, Taishang dongxuan lingbao shoudu yi 太上洞玄靈寶授度儀 $7 \mathrm{~b}-47 \mathrm{a}, \mathrm{DZ} 528$.

${ }^{70}$ An allusion to Zhuangzi's story of the carp in a dry rut. See Zbuangzi jisbi 莊子集 釋, ed. Guo Qingfan 郭慶藩 (1844-1896), “Waiwu 外物," 26.924, Peking: Zhonghua shuju, 1961.

${ }_{71}$ See “Zhu qingyu 主請雨," Zhengyi fawen jing zhangguan pin $4.11 \mathrm{~b}-12 \mathrm{~b}$, and note 6 above. 
From the Lingtai palace 靈臺宮, we respectfully invite one Lord Hanming 漢明君 with twelve hundred officials and generals, including the responsible officers in charge of heavenly thunder 主攝天雷; from the Yuanming palace 元名宮, one Lord Xiao Xuanming 小玄明君 with one hundred and twenty officials and generals, including the responsible officers in charge of the River Count 河伯, Young Master Lü 呂公子, the thirty-six Water Emperors 水帝, twelve River Maidens 溪女, the Water Emperors of the Nine Streams 九江水帝, the Marquis of River Floods 河平侯, with assistant clerks and the mid-section water spirits 中 部水神 who raise clouds and cause rainfall; from the Hetian palace 河天宮, one Lord Beixuan of the Nine Seas 九海北玄君 with one hundred and twenty officials and generals in control of sending down water vapors and issuing wind and thunder; from the Taishan palace 太山宮, the Nine Valleys Lord of Sizhou 泗州九 谷君 with twelve hundred officials and generals in charge of raising water vapors.

Having thus opened the floodgates, there was now a need for fine-tuning. The Petition for Ending Excessive Rain After Praying for Rain ${ }^{72}$ served that purpose. The reference to "court and country" here recalls the state orientation of the ritual, but again the officiant invokes the ancient liturgy of the Heavenly Master community in Hanzhong, here simply called the "old rites." The invited deities are from the same pantheon in the "Categories of Petitions and Officials":

Of late, heat and cold have been deregulated and perverse omens have multiplied. Since Incipient Yang 初陽 (the beginning of spring), there had been a severe drought with no rain. The population lost its farming, cereals withered away. Speaking on behalf of the people's distress, your servant respectfully begged for the clouds to open ${ }^{73}$ and the rain to fall. Your vast beneficence poured down all around and the vapors of $y$ in descended everywhere. Thereupon, the rain did not cease to fall continuously and heavily until the hundred rivers overflowed. The work of the people was wasted, the fields and seedlings swamped. Court and country 朝野 became distraught. They requested your servant to respectfully present this petition, in accordance with the old rites 萏儀. We humbly communicate the appeal that the officials of rains and sources 雨泉官 previously solicited by your servant all return to the Department of Heaven, that the inner officials 中官 register them and make arrangements in view of their reward for meritorious service. We further request that one heavenly duke Lord of Correct Qi 天公正氣君 with one hundred and twenty officials and generals, and Heshang 河上 with one thousand two hundred jade maidens 玉女 descend all together. ${ }^{74}$ We submit our request to the Department of Heaven to stop the rain and shift the wind. May the Earl of Wind 風伯 and Master of Rain 雨師 ${ }^{75}$ conform to the four seasons and eight periods 四時八節 [of the solar year] and not cause errors of

72 “Qingyu de shuiguo zhiyu zhang 請雨得水過止雨章," Chisong zi zhangli 3.3b-4b.

3 Literally, “for the sky to clear" 披雲.

it For these deities, see Zbengyi fawen jing zbangguan pin $4.11 \mathrm{~b}-13 \mathrm{a}$. The latter refers to Heshang zhenren 河上真人. According to Daoyao lingqi shengui pin jing 道要溉祇神鬼品 程: (Six Dynasties and early Tang), 7a, DZ 1201, Heshang gong 河上公, the semimythical commentator of the Daode jing 道徳經 who is also known as Heshang zhangren 河上丈人, belonged to the pantheon of water spirits 水神品.

${ }_{75}$ Gods of wind and rain, mentioned in the Book of Mountains and Seas, Shanbai jing 山海經. The rain master transformed into Chisong zi (see above). 
excess. Gather in the clouds and restrain the mists, let the Three Luminaries 三光 (sun, moon, and stars) shine forth and cause the rain to stop in due time. Let all officials announce their merit and report for rewards.

With the Petition for Preventing Locusts and Rats from Eating Seedlings ${ }^{76}$ we retreat deeper into the farmlands. The text is less stately and more local in tone. There is also a private patron. The specialized pantheon invoked against the vermin corresponds again to a register in Categories of Petitions and Officials. A Heavenly Master scripture and liturgical protocols in the Taoist canon illustrate the ritual context in which this petition was used. ${ }^{77}$

In recent years, field cultivation has been untoward all around. This year, in suchand-such a place, the ears of the grain in the fields have been eaten by a plague of locusts 災蝗. It was impossible to prevent. Your servant was solicited to implore its expulsion 䙑辟. Prostrating myself on the ground, I respectfully submit this petition. On behalf of household $X$, we humbly request the Lord of Heavenly Fields 天田君 from the North Gate Palace 北門管 with one hundred and twenty officials and generals ${ }^{78}$ to take charge of the prevention of crop damage caused by plagues of locusts, insects, and mice, and to order the spoilage due to insects and mice to be entirely eradicated. We further petition the Lord of Heavenly Farmlands 天野君 from the Dijin Palace 地畫宮, with one hundred and twenty officials and generals, to descend for the benefit of farm work and prevent deer, birds, insects, and rats from doing their harm. ${ }^{79}$ We further petition the Lord of Three Qi Yang Origin 三氣陽元君, with a hundred and twenty officials and generals, who reigns in the palace of Yellow Clouds 黄雲宮, to restrain the scourges of birds and beasts and to disable the spirits of the standing cereals 羖稳 from doing harm. ${ }^{80}$ The Void Sovereign Great Tao 虚皇大道 ${ }^{81}$ commands the soil gods 土地 of the locality, the overlords 孟長 of the mountains and forests, the twelve River Maidens 十二溪女, and the County Lords of Soil and Grain 社稷邑 君. ${ }^{22}$ Command that the fields of $\mathrm{X}$ obtain a double harvest and not be stricken by further disasters!

76 “Que chonghuang shuzai shimiao zhang 卻蟲蝗鼠災食苗章,” Chisong zi zbangli $3.4 \mathrm{~b}-5 \mathrm{~b}$.

77 See Taishang yuanshi tianzun shuo xiaotian chonghuang jing 太上元始天尊説消殄蟲蝗 橎, DZ 67, and Daomen dingzbi 道門定制 (1188) 7.28a-30a, DZ 1224.

${ }^{78}$ See “Zhu tianzhong 主田種," Zhengyi fawen jing zhangguan pin $4.2 \mathrm{a}-\mathrm{b}$. Cf. the section on farming and gourds, “Tianzuo guahu 田作瓜颌," ibid., 1.17b.

79 See “Tianzuo guahu 由作瓜颌," Zhengyi fawen jing zbangguan pin 1.17a, where the name of the god is written "Lord of Nine Farmlands" 九野君. The same manual, on 3.10b, lists a "Lord Without Farmlands" 無野君, also of Dijin, in connection with rat plagues.

${ }^{80}$ See Zhengyi fawen jing zhangguan pin $4.2 \mathrm{~b}$. Cf. "Sanqi yang wuyuan jun =氣陽無元 君," Zhengyi fawen jing zhangguan pin 2.6b, and the lord of Three Five Yang Origin (Sanwu yangyuan jun 三五陽元君) in the following petition below.

81 One of the Three Venerables 三尊 of the Shangqing pantheon. See Dongxuan lingbao zbenling weiye tu 1a-b and their genealogy Shangqing sanzun pulu 上清三尊譜錄, DZ 164.

82 Overlords: cf. the petition "Bahe zhang 拔河章," Chisong zi zhangli 5.15a-16a, discussed above; River Maidens, cf. the drought petition above. The classical soil and grain gods had a special altar in the petition ritual area. See Verellen, "Tianshi dao shangzhang keyi," pp. 51-52. 
The Petition for Controlling Rat Plagues ${ }^{83}$ appeals to the same pantheon to contain spoilage due to rats 鼠秏 and invites the White Tiger of Nanshan 南山白 虎 with his generals and troops "to descend all together, seize the swarms of rats within the territory, make them return to places in the open country where there is grain and prevent them from staying within our bounds." ${ }^{84}$

The traditional imperial ritual that opened every plowing season was paired with a sacrifice to the First Sericulturalist 先垔. Silk production being a feminine activity, the empress on that occasion symbolically gathered mulberry leaves for the imperial silkworms. ${ }^{85}$ A category of Heavenly Master scriptures was specially devoted to the cultivation and protection of silkworms. ${ }^{86}$ The Petition for the Protection of Silkworms ${ }^{87}$ features the Heavenly Master sericulture pantheon, corresponding to the departments presiding over silkworms and mulberry trees and the protection of silkworm cultivation in the "Categories of Petitions and Officials." ${ }^{18}$ The petition served in a fertility ritual that worshiped the silkworm clan as a proliferating divine family. The term "silkworm house" 繁室 refers to the hothouses for rearing silkworms and, by extension, the sericulture establishments of the feudal courts in ancient China.

For consecutive years now silkworm cultivation has been unproductive. We fear that an offence has been committed. ${ }^{89}$ Therefore this month, on an auspicious day and at a propitious time, within the residence, we call upon the silkworm houses of the Green Emperor in the east, the Red Emperor in the south, the White Emperor in the west, the Black Emperor in the north, and the Yellow Emperor in the center; the first ancestor 䊁家先祖, the father- and mother-inlaw 公姥, and the descendants 子孫 of the silkworm family; the silkworm house in heaven above and beneath the earth, all thirty-six silkworm houses, to conduct an investigation. Day and night $\mathrm{X}$ is in a state of vexed perplexity as to obtaining relief. He can but wholeheartedly place his trust in the Great Tao. Respectfully he offers these tokens of his sincerity and solicits your servant to submit this petition in supplication.

The real patient on whose behalf the petition is presented, it seems, is the silkworm family. The nominal patron's declining production indicates that the

\footnotetext{
83 “Shou shuzai zhang 收鼠災章," Chisong zi zhangli 3.5b-6b.

${ }^{84}$ See the section on dispelling insect and rat spirits, "Zhu jie chongshu jingguai 主解 蟲鼠精怪,“ in Zhengyi fawen jing zhangguan pin 2.6b.

${ }^{85}$ See Bodde, Festivals in classical China, pp. 263-272.

${ }^{86}$ See Taishang dongxuan lingbao tianzun shuo yangcan yingzhong jing 太上洞玄露寶天尊

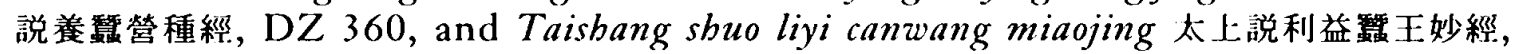
DZ 365.

87 “Baocan zhang 保竞," Chisong zi zhangli 5.16a-17b.

88 “Zhu can sang 主政桑” and “Hu can zi hao 護整滋好," Zhengyi fawen jing zhangguan pin $4.1 \mathrm{a}-2 \mathrm{a}$ and $1.16 \mathrm{~b}-17 \mathrm{a}$, respectively. See also the petitions in Taishang xuanci zhubua zhang 1.9b, 5.1a. Compare the "official" pantheon described in Dieter Kuhn, "Sericultural deities," in Science and civilisation in China, ed. Joseph Needham, vol. 5, part 9, Cambridge: Cambridge University Press, 1988, pp. 247-272.
}

89 Fancu 犯觕 emended as fanchu 犯觸. 
silkworm family is in a "bind." Hence the dispatch of substitute bodies for members of the silkworm family to the five directions of space, a procedure used in healing rituals (see below).

We invite the Five Directions substitute father-in-laws 代公, substitute motherin-laws 代姥, the substitute family first ancestors 代家先祖, substitute family fathers and mothers 代家父母, substitute family descendants 代家子孫, with four directions warriors of the right and left. We appeal to the divine lords 神君 above to descend and settle the Young Ladies of Silkworm Rearing 羕禤之姑 and the Brides of Silkworm Rearing 養覾新婦. ${ }^{90}$ Let the black silkworms be like dragons, the white silkworms like tigers, the sound of their crawling like wind, the sound of their eating like rain, may the sounds reverberate like thunder!

At this point, the officiant reports the presentation of the pledge offerings placed before the altar. Although substitute bodies are not listed among the pledges, as in comparable rituals, the inventory includes "five paper posters with brushes and ink, five items each 紙五貼、筆墨各五事.” The client also provides “one pair of chicken eggs 雞卵一雙.”11

Let there be no taboo violations 禁忌. But if there be cases of death pollution 殗 穢, cause them all to be wiped away. Humbly providing these ritual pledges, we place them before the altar. We worshipfully invite the presence of the Maidens of Silkworm Rearing 盖䇢之女 of the Five Directions; we further invite the Young Ladies of Silkworm Rearing 盖䡤之姑 of the Five Directions; again we invite the Northern Yang Lord Father of Silkworms 翼父北陽之君 and the daughter of the Northern Lady Mother of Silkworms 贅母北君之女. ${ }^{92}$ May the [Bombyx] moths and larvae 蛾整 of the household of $\mathrm{X}$ be satisfactory, proliferate, and continuously multiply. Banish infectuous diseases 㨕疫 and let spoilage from insects and rats be altogether eliminated. Humbly we beg that they may harvest ten thousand bushels of cocoons 䨆 and obtain a thousand pounds of silk thread 絲.

\section{Public safety and morals}

The original existence of more petitions on these topics than we now have can be inferred from the inventory. Three types of petitions are mentioned there that appear to relate to the area of public safety: the Petition for Preventing Injuries 章, the Petition for Stopping Officials 断官章, and the Petition for Keeping Away Robbers 退盗章. ${ }^{93}$ The surviving examples concern tiger plagues, fire omens, and military campaigns. Like the ritual for the protection of silkworms above, the Petition for Eliminating Tiger Plagues ${ }^{94}$ was commissioned by a household. Here the priest identifies himself as holder of a "Heavenly Master register" 天師符籍.

At this time, we experience fearful disasters, tigers and wolves have entered our territory, eating men alive and bringing the six kinds of domestic animals to grief. Day by day and month by month [the plague] is growing more severe, and we

${ }^{90}$ Cf. Zhengyi fawen jing zhangguan pin 1.16b-17a.

91 Chisong zi zhangli $1.16 \mathrm{~b}$.

92 Cf. Zhengyi fawen jing zhangguan pin 4.1 a.

93 The titles are listed in Chisong zi zbangli 1.6b and 1.10a.

94 “Shouchu huzai zhang 收除虎災章," Chisong zi zhangli 3.6b-8a. 
have no means of putting an end to it. It is feared that the lives of the male and female members of household $X$ are in danger. The Net [of Heaven] and Grid [of Earth] 羅網 have become entangled, ${ }^{95}$ and the various interdictions violated: the General of the Great Year 太歲將軍, ${ }^{96}$ the personal destiny in the current year 行 年本命, ${ }^{97}$ the twelve interdictions and taboos 十二禁忌, ${ }^{98}$ Fei-cadavers 帮尸, ${ }^{99}$ stale emanation demons of food and drink 故氣飲食之鬼, ${ }^{100}$ mountain goblins and sea sprites, one hundred and twenty specters, generals defeated in battle since antiquity and generals on the road-all affecting official titles, ${ }^{101}$ they clash with the spirits of the Five Directions 五方神傷, clash with the Danglu spirit 當路神 傷. ${ }^{102}$ We beg not to suffer their perilous harm!

After a series of directional invocations, the petitioner prays that the "members male and female, young and old, oxen, horses, and six kinds of domestic animals of the household $X$ in [such-and-such] county and prefecture may come and go and leave or enter without encountering hardship from the calamities of tiger and wolf, and that such cruel harm be kept from passing these bounds."

The Petition for the Prevention of Fire Omens, ${ }^{103}$ with its apocalyptic overtones, is designed not to put out a fire, but to dispel an ominous sign announcing a public hazard:

Of late, the client has heard and seen delusions. Suddenly, at such-and-such a time, he witnessed a fire omen 火殊 descend at such-and-such a place. Its

${ }^{95}$ See the Petition for Untangling the Net of Heaven and the Grid of Earth under "baleful binds" below.

${ }^{96}$ See Hou Ching-lang, "The Chinese belief in baleful stars," in Facets of Taoism, eds. H. Welch and A. Seidel, New Haven: Yale University Press, 1979, pp. 200-209.

97 Referring to an individual's destiny as determined by conjunctions obtaining in a given year.

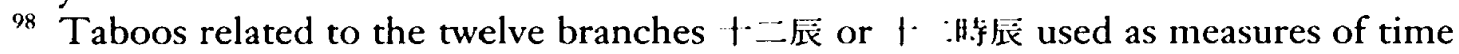
and spatial coordinates. See Chisong zi zhangli $2.10 \mathrm{~b}-11$ a and passim.

${ }_{99}$ A miasmal corpse demon; see also Chisong zi zhangli 3.7a and 6.21a and below (on corpse demons as miasmal pathogens, cf. Strickmann, Chinese magical medicine, 37). Talismans attributed to Lu Xiujing for curing the effects of $F e i$-cadaver miasmas are

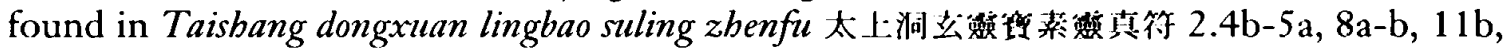
and 15b, DZ 389. The 'Tang liturgy Zhengyi jiaozbai yi IF 一礁'㐌儀 5a, DZ 801, writes feishi 蜚户, perhaps assimilating the demon with the monster of that name in the Book of Mountains and Seas. The same astrological conjunctions occur in Chisong zi zhangli 5.11 a (see below).

${ }^{100}$ Cf. the term “perverse emanation demons of food and drink 逆乘飲食之鬼” in Dengzhen yinjue $3.21 \mathrm{~b}$ and the "contrarious demon thieves of food and drink 飲食横行鬼 賊” wanted for arrest in Cbisong zi zbangli 5.20b and Dengzhen yinjue 3.19a. On stale emenations, see Strickmann, Magical medicine, p. 72.

${ }^{101}$ Low-level specters were wont to assume grand titles. See Lu xiansheng daomen keliie $1 \mathrm{a}$ and the Petition for Dispelling Ghosts below.

${ }^{102}$ Cf. the "Danglu Lord of Fate 當路司命君” in Yuanchen zhangjiao licheng li 1.10a. On the notion of astrological conjunctions clashing with the presiding spatial or temporal deity 神傷, see the commentary to the table of the opening hours of the Gate of Heaven, “Tianmen kai shi 天門開時," Cbisong zi zhangli 1.19a-b.

103 “Shouchu huoyang zhang 收除火殊章," Chisong zi zhangli 4.18b-20a. 
radiance illumined the ground. We fear a death-bringing fire omen spread over the village and invaded the people. Men and women shall meet with disaster, countless the anguished cries of the multitudes of lay and religious!

The petitioners request the Three Bureaus of Heaven to dissipate the fire omen at once. The Earl of Wind and Master of Rain are also invoked to "eliminate the fire omen in such-and-such place and speedily drive it a thousand $l i$ away," an army of Lords Eradicator of Scourges 誅殊君 ${ }^{104}$ to stay the demons of fire omens, and other protectors to raise rain clouds and subdue the fire omen, commanding the disaster not to occur, and no conflagration to break out in the household of $X$ in such-and-such village.

The Petition for Protection on Military Campaign ${ }^{105}$ was commissioned by soldiers for prophylactic rituals before leaving on campaign. The invocations invite the lords of the outlying barbarian tribes and the center (see below) to "cause $\mathrm{X}$ not to be struck by blades and escape mortal danger."

Long is the road towards the ferocious enemy, traversing streams and mountains, crossing the rivers Huai 淮 and $\mathrm{Si}$ 泗. ${ }^{106}$ In the midst of naked blades, presently the evil of the sword is upon us, cruelly stoking the flames. Military discipline is severe, in action the killing is brutal. Baleful influences 妨惡 hold sway, compelling men to commit violence. The merits of mortals 肉人 are slight, insufficient to ward off disaster. It is feared that $\mathrm{X}$ may not come through this critical juncture unscathed. The well-intentioned rely on meritorious acts. He has come to the [sanctuary of the] diocese and requested your servant to beg for protection. On his behalf, we humbly present this petition...

No petition models survive for rituals dealing with offences against the precepts and public morality, but the inventory again preserves the titles of several such types: Petition of Confession and Repentance for Offences against the Precepts 違反科要 首謝乞原章, Five Tombs Propitiation Petition for Official and Private Wrongdoings 官 私各謫死病相連斷五墓殊注章, and Petition for Locking up Quarrels and Slander 鎖口 舌誹謗章. ${ }^{107}$ The themes suggested by these titles correspond to Heavenly Master teachings on public morality as reflected, for example, in the Hundred and Eighty Precepts and the Demon Statutes of Nüqing.

\section{Personal destiny}

Most petitions of repentance aim at redeeming an individual's personal destiny from liabilities incurred through sin. In the Petition for Announcing Repentance in View of Personal Destiny, ${ }^{108}$ the supplicant's spirits are disturbed,

${ }^{104}$ On these lords, see also Zbengyi fawen jing zhangguan pin $1.1 \mathrm{~b}, 14 \mathrm{a}$ and Cbisong $z i$ zhangli $5.22 \mathrm{a}, 6.19 \mathrm{~b}$.

105 “Baohu rongzheng zhang 保護戎征章," Chisong zi zhangli 6.26a-27a.

${ }^{106}$ The great confluent of the Yangzi, originating in Henan, and a river in Shandong, respectively.

${ }^{107}$ Titles listed in Chisong zi zhangli 1.8a, 1.10b, and 1.13b. On the evil of slander, see

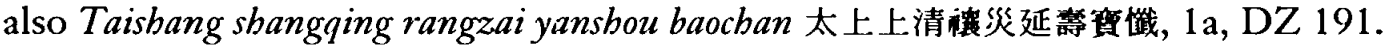

108 “Benming xieguo kouqi zhang 本命謝過口啓章," Chisong zi zhangli 3.14a-16b. 
causing him to fear retribution for his own and his ancestors' wrongdoings. In the manner of the earliest Heavenly Master petitions, the confession is addressed to the Three Officials:

[The patient's] vital forces 神氣 are disturbed, his three bun-souls untogether, and his seven $p o$-souls restless. ${ }^{109}$ In fear and trepidation we reverently knock our heads to the ground before the Sovereign Jade Emperor 皇上玉帝. Your servant and others present, through our comportment over seven generations of ancestors, have committed crimes in the world of yin and faults in the world of yang. We are guilty of the sins of accumulated evildoing, as well as the taking of life. We petition the Three Officials, imploring them to order the ten thousand faults of your servant $X$ to be wiped out from now on, to lift the charges against him, and let the miasmal $q i$ be extirpated. The nine blessings and eternal peace be upon his seven generations of ancestors, his father and mother, and his descendants reaching down to the fifth generation. Let their bun and po souls be conveyed upward and let them return to the womb and be reborn as infants 反胎還嬰.

\section{Disease}

Since the perceived causes of disease were manifold and ill-defined, this category is difficult to demarcate. To the extent that illness could be the result of anything from sin, taboo violations, and the grievances of the dead to astrological and magical influences or noxious emanations, it is inseparable from the rest of the Heavenly Master liturgical agenda. On the other hand, the gods listed under the Invitation of Officials for invocation in healing rituals are set out in relation to disease symptoms. ${ }^{110}$ This suggests a two-pronged approach to healing rituals: while propitiating the judicial authorities involved in the deeper causes of illness in the moral sphere, the rituals also addressed the agents directly responsible for causing disease symptoms.

Illness appears in Master Red Pine's almanac mostly as a problem concerning individuals. Rituals to control an epidemic befalling the community are the exception. ${ }^{111}$ The fact that mental disturbances-confused thoughts and dreams, nightmares, illusions - are frequently mentioned alongside physical ailments underlines the psychosomatic conception of disease and its fundamental connection with demonic possession. Delusions are not dismissed as unreal, but scrutinized as irruptions from the unseen world (cf. the Petition for the Prevention of Fire Omens above). Another remarkable feature is the finely graded differentiation applied to the duration of the disease: between incipient 始覺有疾, continuous 疾病累日, prolonged 積病, long-standing 久病, and chronic 疾厄沈滞, 滞疾. Possibly, moral implications of a failure to get better are suggested by these terms. The detractors of Heavenly Master ritual healing certainly claimed that continuing disease was regarded as due to a lack of faith:

${ }^{10 \%}$ Cf. the Petition for Unbinding Curses discussed below (Chisong zi zhangli 3.8a-10a).

${ }^{110}$ See “Qingguan 請它," Chisong zi zhangli 2.18b-22a.

111 “Duan wen du yi zhang 断瘟毒疫章," Chisong zi zhangli 3.29a-31a. Though the text speaks of the effect of the epidemic on the "good people," the ritual is commissioned by a household. 
The master [...] instructed the sick to kowtow and to reflect on their transgressions, and then gave them charm water to drink. If the disease was healed within a short period of time, then he would say that the person in question was a believer in the Way; if no healing took place, then it was due to lack of faith in the Tao. ${ }^{112}$

Master Red Pine's almanac more subtly links intractable disease to the obscure and tangled proceedings of underworld litigation, ancestral guilt transmission, and the multiplicity of baleful influences liable to produce the ill effect. While diagnosis and divination have a place in ritual healing, many petition texts suggest that such procedures are regarded as formalities yielding no more than tentative results. ${ }^{113}$ Covering a wide range of conceivable causes under generic formulas of repentance and supplication, officiants and patients humbly acknowledge to the divine powers the impossibility of knowing the deep causes of illness. In practice, the petitioner's line of attack is ingenuously based on trial and error:

The Taizhen ke states: In all cases of illness, first present a plaint 首状 petition. Failing recovery, present a petition for discharge from inquest 解考. ${ }^{114}$ Still failing recovery, present a petition for acquittal from indictments against deceased ancestors 解先亡罪謫. Failing recovery, present a petition for transfer 遷達. ${ }^{15}$ In case of aggravation, present a petition for the elimination or incarceration of miasmal demons 却殺收注鬼. If thwarted, present a major petition for release from misfortune and evil 解䙤惡. Failing improvement, present a petition for release from indictments of the five tombs 解五墓謫 (see examples of this below). Failing improvement, present a petition for sustaining frailty and traversing calamity 扶衰 度厄 (see also below). Failing recovery, present a petition for the return of the bunsouls and the restitution of the po-souls 還魂復魄. ${ }^{116}$ Failing recovery, present a petition for settling tombs and delivery from strife due to the Five Soils 安墓解五土 耗害. ${ }^{117}$ Failing recovery, present a petition for pacifying the home, stabilizing the spirits, and eliminating demons 安宅鎮神驅除收鬼. Failing recovery, present a petition for resolving major inquests within and without 分解中外大考.

The passage continues to name petitions for acute 危急, chronic 進退, and critical 大危篤 conditions and to list further baleful influences. The unwarranted solicitation of petitions for severe cases was liable to a second-degree sentence = 形論, carrying as punishment twenty days of road sweeping or bridge repair. ${ }^{118}$ The following example is titled Petition for Healing Diseases: ${ }^{19}$

${ }^{112}$ Dianliue, quoted in Sanguo zhi 8.264.

${ }^{113}$ On their place in medical practice, see Donald Harper, "Iatromancy, diagnosis, and prognosis in early Chinese medicine," in Innovation in Chinese medicine, ed. Elisabeth Hsii, Cambridge: Cambridge University Press, 2001, pp. 99-120.

${ }^{114}$ The healing petition “Jibing yizhi zhang 疾病醫治章," discussed below (Chisong $z i$ zhangli $3.21 \mathrm{~b}$ ) appeals to the Lord of Discharge from Inquest.

115 I.e., promotion to paradise of deceased ancestors undergoing trial and punishment.

116 See the Petition for Unbinding Curses discussed below.

${ }^{117}$ I.e., the five types of earth spirits, here specifically in their capacity to unsettle tombs. Cf. below and Zhen'gao 10.16b.

118 “Qingguan 請官," Chisong zi zhangli 2.18b-19a.

119 “Jibing yizhi zhang 疾病醫治章, Chisong zi zhangli 3.20b-21b. 
We respectfully submit, et cetera 云云. ${ }^{120}$ In recent days, [the patient] has contracted a disease 染疾 that threatens to engulf his survival 没溺生路. He has approached your servant to request the presentation of a petition to the Three Heavens Department 三天曹 in the hope of redeeming his life 拔睸. For ten days, he has been suffering unregulated chills and heat 寒暑不節 while [the circulation in] his veins is errant 㬺理失所. Either he caught this disease because he was exposed to the wind and lay in the cold 臥冷, or he is being punished with the Five Chastisements 五形 and Three Scourges 三災. ${ }^{121}$ In our benighted ignorance we do not know, and ask that the case be heard and investigated 省理. We send up our supplication to the Five Directions to engender the $q i$ with which to effect a healing. We especially pray to the Most High Limitless Great Tao, the Most High Lord Lao, all the lords and elders, the Lord Heavenly Master, the Three Masters Lords and Ladies 三師君夫人, ${ }^{122}$ Merciful Father and Holy Mother 慈父聖母, ${ }^{123}$ to remember him kindly. May they grant us the $q i$ of the Tao with which to shelter his body. We respectfully call upon the Lords Heavenly Physician 天醫 and Great Physician 太醫, in the seats of honor in the Department of Heaven, with their twelve officers, to descend into his body to the seat of the illness and effect a cure. We send up our request to the fifteen merit officers of healing 治病功曹 on his behalf. ${ }^{124}$ We send up our request to the Department of Heaven to expunge the causes [of the disease] flowing from faults and transgressions committed in his previous existences 前世 and in this life, and to restore all deficiencies in his five viscera, four limbs, and hundred arteries. We next beseech Green of the east to engender its $q i$; Red of the south to engender its $q i$; White of the west to engender its $q i$; Black of the north to engender its $q i$; Yellow of the center to engender its $q i$, and that they may all descend into his body. We further ask the Lord of Acquittals 解考君, the Lord Savior 度命君, the Lord Extender of Life 网算君, ${ }^{225}$ the Lord

${ }^{120}$ In the place of the omission indicated in the model, the petition would include the client's personal particulars here.

${ }^{121}$ The five punishments of ancient China: tattooing 墨, amputation of the nose 副, amputation of the feet 非, castration 宮, and death penalty 大辟. See Shangshu 尚書, "Shundian" 3.44-45, Shisan jing + predicted by the Buddhist apocalypse: sword, pestilence, and famine, or fire, flood, and wind.

${ }^{122}$ I.e., the first three Heavenly Masters and their wives; cf. the complete expression “the Heavenly Master 天師i (i.e. Zhang Daoling 張道陵), the Successor (Zhang Heng 張 衡), the Second Successor 系師 (Zhang Lu 張魯), Three Masters Lords and Ladies" in Chisong zi zhangli 5.9a. Cf. Shangqing huangshu guodu yi $3 \mathrm{a}$.

${ }^{123} \mathrm{~A}$ generic appellation, sometimes applied to the Tao (Zhengyi fawen taishang wailu yi 正一法文太上外籍儀 27b, DZ 1243). See also Shangging buangshu guodu yi 4b, 21 a, Wusbang biyao 無上秘要 (ca. 574) 50.17a, DZ 1138 and below.

${ }^{124}$ For the Heavenly and Great Physicians and their entourage, as well as the formula for their descent into the patient's body, see Zhengyi fawen jing zhangguan pin $1.12 \mathrm{a}$; see also almanac indications in Chisong zi zhangli $2.1 \mathrm{lb}$. The merit officers of healing, too, form part of the ancient Heavenly Master healing pantheon. They feature in Shangqing buangshu guodu yi (3a) and other early scriptures.

${ }^{125}$ Lord Savior, cf. the Gold and Purple Effigy Petition below; Lord Extender of Life, cf. the Lords Extenders of Years and Augmenters of Longevity in the following petition. 
Protector of the People 防民君, the Lord Eradicator of Scourges and Disasters 誅 殊禍君, ${ }^{126}$ the general-in-chief Roamer in the Net [of Heaven] 遊羅大將軍, and the general-in-chief of the Terrestrial Realm 地境大將軍 to each control the demons of heterodox spirits, stale emanations, and pestilential poisons, and let the patient recover et cetera 云云. ${ }^{127}$

Other healing petitions focus neither on specific symptoms nor possible causes of disease, offering instead catchall therapeutic procedures or panacea. The use of "substitute bodies" 替身 is an example. Found in various Chinese purification rituals, ${ }^{128}$ it belongs to a universal archetype: in the West, the Judeo-Christian expulsion of the scapegoat and the ancient Greek pharmakos banished pollution and atoned individual or collective guilt by transferring them onto a disposable victim. In China, the substitution of funerary effigies 俑 for sacrificial victims is an example of this type of liability transfer. In civil law, it had a further parallel in the delegation of corvée and military conscription duties to a hired replacement. ${ }^{129}$ Figurines of various materials served as ritual substitute bodies in Han funerary rites, ${ }^{130}$ as well as Heavenly Master petition rituals. Called "replacement figures" 代形 in this context, they are major, and often costly items among the pledge offerings prescribed by the Petition Almanac:

Silver effigy substitute body petition in view in continuous and life-threatening disease. The number of the silver foil figurines 銀箔人 depends on the size of the household, one figure for each person. Use silver, not pewter [...] After the presentation of the petition, discard them into the water. ${ }^{131}$

'I he effigies were mostly intended for healing or related purification purposes: "With one gold effigy, we call on the Northern Dipper to save [the patron's] life and eradicate the adversity of death."132 The following example is titled Gold and Purple Effigy Petition for Severe Distress from Chronic Disease. ${ }^{133}$ "Gold" here refers to the substance of the effigy, "purple" to a length of purple-threaded silk attached to it. Possibly this attachment served as the medium of transfer between the patient and the substitute body, the way a thread is used in the equivalent modern ritual. Purple-threaded silk was a material deemed "eminent" 疋 and worthy of pledges provided by princes. Forty feet of this fabric were to be

${ }^{126}$ Cf. the Petition for the Prevention of Fire Omens above.

${ }^{127}$ Cf. the petitions devoted to the Net of Heaven and Grid of Earth below.

${ }^{128}$ Kristofer Schipper, "Chiens de paille et tigres en papier - une pratique rituelle et ses gloses," Extrême Orient - Extrême Occident 6 (1985), pp. 83-94, describes the modern Chinese practice and surveys the classical tradition behind it.

${ }^{129}$ Cf. See Anthony F.P. Hulsewé, Remnants of Han law, Leiden: E.J. Brill, 1955, p. 17. On funerary effigies as substitute bodies, cf. Chen Guofu 陳國符, Daozang yuanliu kao 道藏源流考, Peking: Zhonghua shuju, 1963, p. 284.

${ }^{130}$ See e.g. Ikeda On 池田温, “Chūgoku rekidai boken ryakkō 中国歴代墓穷略考,” Tōyō bunka kenkyüjo kiyo 東洋文化研究所紀要 86 (1981), p. 273.

131 “Bingsi bujue yinren daixing zhang 病死不絶銀人代形章," Chisong zi zhangli $1.11 \mathrm{~b}$.

The petition text is lost. Water was the preferred medium of expulsion; see also below.

132 “Yima zhang yi yun kaidu zhang 驛馬章亦云開度章," Chisong zi zhangli 4.5b.

133 “Jiubing dae jinzi daixing zhang 久病大厄金紫代形章," Chisong zi zhangli 6.2b-9b. 
provided as a pledge for the present ritual. ${ }^{134}$ The following Invitation of the Officials informs us that the therapeutic transfer involved an exchange of the patient's and substitute's civil and physical identities:

On behalf of $\mathrm{X}$ 某, I invite the imperial lords of the Thirty-two Heavens 三十二 天帝君, the Controllers of Longevity 長生司馬, ${ }^{135}$ the Effigy Savior Primordial Lords of Nanchang [palace] 代形度命南昌元君, and Life Superintendent emissaries 監生使者, ${ }^{136}$ thirty-two persons each, to mount their flying dragons and feathered chariots. Let the emperors of the Thirty-two Heavens come down together with nine thousand billion infantry and horse each.

Offering the gold effigy of $\mathrm{X}$ 某金人 with purple-threaded silk 紫紋, I pay my respects in the palace administrations of the lodge regulators for orbiting stars 曆 星檢宿宮曹 in the Thirty-two Heavens: may they trade names and exchange bodies 貿名易形! I further invite the perfected gods of mysterious origin 真神玄 $\overrightarrow{\mathrm{U}}^{137}$ to engender vital energies 生氣 to descend into the body of X. Further, let his [new?] name be entered upon the Register of Life 注上生籍 and his life extended without limit. I respectfully invite the Lords Extender of Years and Augmenter of Longevity 延年益壽君, five each, with one hundred and twenty officials and generals to come down together.

With pledge offerings comprising the gold effigy of $\mathrm{X}$ as a substitute body 代形 and purple-threaded silk, I pay my respects in the palace of $q i$-generation of Highest Clarity Mysterious Origin 太清玄元 and beg that instructions be issued to the Lord Calculator of Life Stars 星度算君, and to the Lords in charge of Trading Names and Exchanging Bodies 貿名易形君 and of Escaping Death and Acceding to Life 脱死上牛君. I also invite the merit officers and envoys from within your servant's body 功曹使者 and the summoners of Taiyin, lords and clerks 太陰考召君吏. ${ }^{138}$

Offering the gold effigy of $\mathrm{X}$ with purple-threaded silk, I pay my respects to Taiyin in the Northern Dipper [...], in charge of the Register of Death stored in the Chest of Precious Jade 璧模之中: Swap personal names with $\mathrm{X}$ and exchange his own body! Inscribe his name in the Register of Life in the Jade Calendar 玉曆之中. ${ }^{139}$

This point in the invocation is developed into an extended litany of the deities of the patient's horoscope and destiny gods in the twenty-eight stellar lodges, the Northern Dipper and Three Terraces constellations, the Four Seasons and Five Phases, and the seven stars of the Dipper. A further series of invocations

${ }^{134}$ Chisong zi zhangli 1.18a, 1.17a, and 6.3a. "Gold and purple" in China generally evoke a superior status, e.g. referring to the official lords of the golden seal and purple ribbon.

${ }^{135}$ Cf. Wushang biyao $9.7 \mathrm{a}-\mathrm{b}$.

${ }^{136}$ Cf. the titles of the five directional Lords Life Superintendant Saviors 監生度命君 below (Cbisong zi zhangli 6.6a-7a).

${ }^{137}$ Referring to various deities. See Dengzhen yinjue $3.7 \mathrm{a}-8 \mathrm{~b}$.

${ }^{138} \mathrm{Lu}$ Xiujing explains that these summoners from the world of the dead were dispatched by the Three Officials to keep the households of the people under surveillance. See Lu xiansheng daomen kelüe $9 \mathrm{a}$.

${ }^{139}$ Chisong zi zhangli 6.4b-5b. The Jade Calendar was the register of the immortals. See Wushang biyao 52.6a and Kristofer Schipper, "The inner world of the Lao-tzu chungching," in Time and space in Chinese culture, eds. Chun-chieh Huang and Erik Zürcher, Leiden: E.J. Brill, 1995, pp. 116-117. 
then seeks to apply the identity change for the patient in the registries of the four corners of the world and the center. Like all directional litanies, these invocations begin in the East and turn clockwise:

We beg to trouble the Green Emperor in the Qinghua 青華 Superior Palace of Nine Mysteries ${ }^{1+0}$ in the extreme East, the Lord Life Superintendent Savior 監生 度命君, the Lord of Altering Names and Exchanging Bodies, and the Lord of Immortal Transcendence 神仙度世君, one person each with nine million soldiers each, to come down all together, flying ten thousand $l i$ mounted upon feathered chariots of azure clouds. Offering the gold effigy of $\mathrm{X}$ as a substitute body with purple-threaded silk, I pay my respects at the Palace of Eternal Life 長生宮 on behalf of $\mathrm{X}$ to trade his name and exchange his body and to inscribe him upon the Register of Life in the Jade Calendar. May the Green Emperor and his worthies extend [the patient's] life without limit. ${ }^{141}$

The same formula is addressed, with corresponding invocations, to the south, west, north, and center. Liturgically, the invocations were pronounced before the altars of the Green, Red, White, and Black Emperors on the four sides of the ritual area, and the main altar that held the emplacement of the Yellow Emperor. Two tables in front of the main altar were dedicated to the stars of the Northern Dipper and the Three Terraces, respectively, while other tables and votive lamps represented the twenty-eight stellar lodges and the cyclical markers of time and space invoked in this petition. ${ }^{142}$

The ritual function of the effigy, then, was to release the patient from his affliction, transferring it to a substitute victim by "trading names and exchanging bodies." The release was ultimately conceptualized as an administrative intercession in the registry of fate. To ensure that the identity change would take effect in all quarters, the effigy was successively dispatched before the gods and officials reigning over the five directions of space. Another petition required the provision of "five pewter effigies 錫人五身 to call on the Five Directions on behalf of $X$ to substitute his body and exchange his name 代形易名."143

Broadly conceived as a matter of guilt expiation and attaining release from retribution for taboo violations, healing rituals frequently focused on the world of the dead. This was an area where the accumulated guilt inherited from ancestors cohabited uneasily with a host of taboo interdictions, involving the gods of the soil, and the dark implications of after-death reckoning. The miasmal exhalations of death polluted the living, enveloping them in contagion. Tombs were consequently objects of a wide range of healing and apotropaic rituals. They will be discussed in different contexts below.

${ }^{1+0}$ Palace in the Eastern Sea, cf. Dongxuan lingbao zbenling weiye tu 洞玄瑾寶真位業圖 1.3b, DZ 167.

${ }^{141}$ Chisong zi zhangli 6.6a. For the Palace of Eternal Life, see also the Deletion from the Death Registers of Mt. Taishan below and Wushang biyao 29.3a-4a.

${ }^{142}$ Chisong zi zhangli 6.6a-7a. On the altar arrangements and directional invocations in the petition ritual, see Verellen, "Tianshi dao shangzhang keyi," pp. 51-54.

143 “Qingsi baming zhang 青絲拔命章," Chisong zi zhangli 3.20a. This petition is further discussed below. 


\section{Other baleful binds}

The Tang liturgical collection of Orthodox One Rites for Exteriorizing the Officials and Petitioning and the contemporary Scripture Spoken by the Most High Lord Lao for Dissolving Curses exemplify longstanding ritual practices for unbinding curses and driving out possessions caused by sorcery. ${ }^{144}$ This tradition is richly documented in Master Red Pine's almanac by petition models concerned with spells, demonic sorcery, and harmful astrological conjunctions. In the Orthodox One Rites, the putative spell binder is referred to as "evildoer" 惡人. ${ }^{145}$ One petition there aims at obtaining release from the "fetters and shackles of prison” 年獄桎梏, in which transgressors were bound, by men or demons, on orders of the Three Officials. ${ }^{146}$ The Petition for Unbinding Curses ${ }^{1+7}$ in Red Pine's almanac is close to such materials in intent and language and was clearly used in a similar liturgical setting:

Of late the resident has encountered frustrations 輇軻; his dreams and thoughts are confused, he is subject to freakish delusions, while devilish omens keep arising. His four limbs feel heavy, his complexion is sallow. His spirits are adrift and no longer adhere to his body.

Divination 占筮 has ascertained that an evildoer 惡人 successively cast spells 謆禱 for a hundred curses 呪詛, implicating heaven and earth, summoning demons and calling upon spirits. Either the evildoer made an engraving of the [victim's] name and family name, or he drew his likeness, or he pierced the heart [of the likeness] with a knife, or cut [the victim's] hair and clipped his fingernails, soliciting spirits and soil gods. It is feared that the victim has been seized by demons of a hundred allegiances 百盟之鬼. ${ }^{1+8}$ [The client] does not know by what acts of merit release can be obtained and his body and soul safeguarded. He can but with a loyal heart conduct a Retreat and offer ritual pledges 持凨儀信. Humbly placing his trust in the Great Tao, he has put his case before your servant requesting the presentation of a petition to reverse and untie the curse 䧽解哠詛. Reverently prostrating myself on his behalf, I present this petition addressed to the Department of Heaven.

This is followed by an enumeration of seven conjectural periods or locations in which the spell might have originated, each accompanied by a corresponding invocation, beginning with the lords of the barbarian tribes in the four directions and of the central kingdom that are frequently invoked in Heavenly Master ritual: ${ }^{149}$

${ }^{1+4}$ Zhengyi chuguan zhangyi 正-出倌章儀, DZ 795, and Taishang laojun sbuo jieshi zbouzu jing 太 1 : 老君説解釋咒詛經, DZ 652 .

${ }^{145}$ Zhengyi chuguan zhangyi $2 \mathrm{~b}$ and passim. Elsewhere in Heavenly Master writings the term has the less specific connotation of "bad person" as opposed to

${ }^{1+6} Z$ Zhengyi chuguan zhangyi 10a-12a. C. Zhengyi fawen jing zhangguan pin $2.7 \mathrm{~b}$. On fetters and shackles, cf. Zhen'gao 6.8b; demon prisons, Taishang xuanci zbubua zhang $1.15 \mathrm{~b}, 5.11 \mathrm{a}$; Three Officials retribution, Lu xiansheng daomen kelïe 9a.

147 “Jie zhouzu zhang 解品詛章," Chisong zi zhangli 3.8a-10a.

${ }^{1+8}$ Presumably referring to demons that were not party to the Heavenly Master's Orthodox One Covenant, zhengyi mengwei 正一盟威.

${ }^{149}$ See e.g. the modern register Taishang zhengyi jie wuyin zhouzu bilu 太上正一解五音 咒詛必等 1b, DZ 1217. 
(1) if the victim's body was cursed during the three months of spring, pray to the lords of the nine tribes of Yi-barbarians 九夷甲乙君 in the east to reverse and untie it; (2) if in the summer, pray to the lords of the eight tribes of Man-barbarians 八䄷 in the south; (3) likewise, for the fall: the lords of the six Rong 戎 in the west; (4) winter: the lords of the five $\mathrm{Di}$ 狄 in the north; (5) if the curse took effect in the months of the four seasons 四季之月, ${ }^{150}$ make a vow to the lords of the three Qin 三 秦 in the center ${ }^{151}$ to annul and untie it; (6) if it originated in the twenty-eight stellar lodges 二十八缩, invoke the lord of the stellar lodge 星缩 in the appropriate quadrant; (7) or again, an image was drawn or heart pierced by the evildoer, or roadside shrine spirits, soil gods, spirits of altars, prisons, trees, wells, stoves, river gods, or heterodox masters and family demons are responsible.

The directional invocations, a characteristic feature of all Chinese apotropaic rites, clearly have a special place in petitions seeking release from possession by agents of unknown identity and location. ${ }^{152}$ In all events, the petitioner supplicates the Most High Great Tao, Most High Lord Lao, Most High elders, the Three Masters Lords Heavenly Masters and Lady Masters, ${ }^{153}$ and others including the lord Overturner 翻倒君 [of curses] with one hundred thousand troops:

All at once descend and on behalf of $X$ release his three bun-souls and seven posouls, return his bun-souls and subdue his po-souls, harmonize his vital forces 神 氣, and break up the thousand evils and ten thousand demons within his body that they may never again create a disturbance. Let all malign spirits and curses be entirely purged. The heavenly officials invited shall be promoted and rewarded in accordance with your servant's Announcement of Merit.

The opening declaration of the Petition for Dispelling Ghosts ${ }^{154}$ states that of late the dwelling had been unsettled by disturbances due to evil spirits. Repeated misfortunes had already occurred when suddenly a goblin of a certain directional color made its apparition. The victims therefore request a petition for the elimination of the hundred goblins 消蕩百怪章. As these potentially emanate from all points of the compass, the petition takes the form of a five-fold litany, following a directional correlation with the five planets:

The green goblins of the east exalt themselves as Jupiter 歲星 and falsely act as

${ }^{150}$ The beginning months of the seasons, i.e., the third (spring), sixth (summer), ninth (autumn), and twelfth (winter) lunar months.

${ }^{151}$ Referring to the division of China after the demise of the Qin dynasty in $206 \mathrm{BC}$. See Sbiji 史記 6.275, Zhonghua edition. Directional invocations of the barbarian and central lords are found in many petitions in Master Red Pine's Almanac and elsewhere (e.g., Taishang xuanci zhubua zhang $2.7 \mathrm{a}$ and $13 \mathrm{a}$ ). On the invocation of these lords in the rite of lighting the incense burner 發嘘, see Verellen, "Tianshi dao shangzhang keyi," p. 55.

${ }^{152}$ Taishang laojun shuo jiesbi zhouzu jing $1 \mathrm{~b}$ and its Buddhist counterpart recovered from Dunhuang, Foshuo zhoumei jing 佛説咒魅經 1383c, 1384b, T. 85, no. 2882, invoke the aid of the emperors of the Five Directions; the latter, in addition, the twenty-eight stellar mansions of the zodiac. See also Strickmann, Magical medicine, pp. 7-8, 133-135.

${ }^{153}$ Referring to the first three Heavenly Masters and their wives. See Dengzben yinjue 3.8a and cf. the Petition for Healing Diseases above.

154 “Xiaoguai zhang 消怪章," Chisong zi zhangli 3.10a-11b. 
phantoms 祅怪. ${ }^{155}$ They are the spirits of old trees that animate green things. Their harm is manifold. Supplicate the Green Emperor of the east 東方青帝 to eliminate their devilish scourge. The red goblins of the south exalt themselves as Mars 笑惑. They animate red things and are bent on visiting harm. Pray to the Red Emperor of the south to eliminate their devilish scourge. The white goblins of the west exalt themselves as Venus 太白. They animate white things, are devoted to violent mischief, and pose as freakish monsters. Pray to the White Emperor of the west to eliminate their devilish scourge. The black goblins of the north exalt themselves as Mercury 辰星. These are the turtle spirits of springs and sources 發泉源繁之精. They animate black things and switch around names and surnames. ${ }^{156}$ Pray to the Black Emperor of the north to eliminate their devilish scourge. The yellow goblins of the center exalt themselves as Saturn 鎮星. They animate yellow things, impersonate deceased ancestors 託號家親, accumulate misfortunes, and act as freakish monsters. Pray to the Yellow Emperor of the center to eliminate their devilish scourge.

Horoscopic rituals were concerned with the collision of a victim's personal destiny configuration with baleful stars like the Great Year 太葴 and the Dog of Heaven 天 狗. ${ }^{157}$ Equally dreaded was entanglement in unfavorable astrological configurations like the Net of Heaven and Grid of Earth 天羅地網. ${ }^{158}$ Master Red Pine's almanac points out, among other "considerata when reckoning a person's fate in view of a petition offering” 章醮推人年命切須看之, that the Net of Heaven 天羅 was associated with the branches $x u$ 成 and bai 亥 and the Grid of Earth 地網 with chen 辰 and $s i$ 巳. ${ }^{159}$ In their spatial disposition, these branches correspond respectively to NW and SE on the compass and to the gate of heaven 天門 and the earth door 地戸 in the layout of the altar for the petition offering. ${ }^{160}$ The Petition for Untangling the Net of Heaven and the Grid of Earth ${ }^{161}$ tells us more:

[Client] $X$ and his wife and children have run into adversity. Perhaps they are in a bind 紱結 with respect to the Net of Heaven and the Grid of Earth. ${ }^{162}$ They have brought their case before your servant and requested a petition. With his shallow learning, your servant has little understanding of meteorological divination 氣候 ${ }^{163}$

${ }^{155} \mathrm{Cf}$. the false assumption of titles by illegitimate specters mentioned in the introduction above.

${ }^{156}$ Visiting undeserved afflictions on the innocent. See the remarks on registration in the introduction, p. 297 above.

${ }^{157}$ See Chisong zi zhangli 2.13b-15a and Hou Ching-lang, "The Chinese belief in baleful stars," pp. 200-209, 224.

${ }^{158}$ See Kalinowski, "La littérature divinatoire dans le Daozang," p. 100.

159 “Tianluo digang 天羅地網," Chisong zi zhangli $2.8 \mathrm{~b}$.

${ }^{160}$ See figure 2 in Verellen, "Tianshi dao shangzhang keyi," p. 53.

161 “Jie tianluo digang zhang 解火羅地網章," Chisong zi zhangli $4.2 \mathrm{~b}-4 \mathrm{~b}$.

${ }^{162}$ Cf. Chisong zi zhangli 3.18a, "Perhaps they have become entangled by the Net of Heaven and the Grid of Earth 恐天羅地網所見緗綿。”

${ }^{163}$ Including astrological observation. See Yuyang qibou qinji 雨暘氣候親機, DZ 1275. The term bouqi also refers to the twenty-four periods of seasonal change 節氣 and seventy-two five-day periods 候 of the solar year. Further on (4.3b), the petitioners refers to "the $q i$ of the five directions and the bou of the twelve periods [of the day] 五方 之氣十一時候.” 
and no mind for calculations 算術. To tell [his client's] fortune 曆數, he depends entirely on the six decades 六甲 [of the sexagesimal cycle], the five phases 五行, and the alternation of [the trigrams] bo 剥 and $f u$ 復. ${ }^{164}$

It is held that xubai 戊亥, the region of extreme yang 絶陽之郷, is the Net of Heaven, while chensi 辰已, the territory of extreme yin 絶陰之地, constitutes the Grid of Earth. When a person's destiny in a given year 年命 encounters these, he or she suffers disaster. When a man's personal destiny 本命 collides with Great Year or when Gongcao 功曹 invades his birth month, this is [a case of] the Net of Heaven; when Chuansong 傅送 invades the month of his conception, it is the Grid of Earth. When a woman's personal destiny collides with the Current Year 行年, it is the Net of Heaven; when Hekui 河鬼斗 invades the month of her conception, it is the Grid of Earth. ... ${ }^{165}$

After enumerating further conjunctions resulting in entanglement with the Net or Grid, the petitioner concludes that the household of $\mathrm{X}$, old and young, have indeed offended the Net and Grid in the Five Directions and that the configurations of the nine palaces and eight trigrams governing their fate are in mutual conflict. To remedy this situation, he first lists his client's pledge offerings and then launches into the familiar directional invocation of the lords of the four quadrants and the center to dispel five-colored toxins emanating from their respective direction. Resuming his didactic vein, the petitioner next discourses on the "three fives" 三五 and their bearing on the victim's predicament:

Your servant has heard that the upper three fives are heaven, the middle three fives man, and the lower three fives earth. Heaven has five phases 五行, earth has five vital energies 五氣, and man five constants 五常. ${ }^{166}$ As long as the five phases of heaven do not fail, sun and moon are bright. As long as the five vital energies of the earth are not wanting, the myriad creatures multiply. As long as man is not amiss in the five constants, he can live a long life and by means of the rites and music maintain integrity. It appears that the five vital energies of the family $\mathrm{X}$ are out of harmony. Their internal organs are in discord, and the five phases counteract each other...

In addition to astral and soil taboos, the element water also held menacing potentials for infraction. Offenses against the Three Officials of heaven, earth, and water and the various deities representing these domains, such as the overlords of the five peaks, four waterways, and mountains and rivers 天地水三官五狺西㵋山林孟

${ }^{164}$ Meaning "stripped bare" and "cycle." Together they signify the turn of the wheel of fortune, as in the expression "after reaching rock bottom, good fortune is bound to return 剥極必復."

${ }^{165}$ On the interference of the asterisms Gongcao, Chuansong, and Hekui with the binomials of time and space, cf. Taishang xuanci zhubua zbang $1.5 \mathrm{a}$. See also the discussion of destiny rituals and horoscopic distinctions that apply to the fate of men and women, respectively, in Verellen, "Tianshi dao shangzhang keyi," p. 50, and Appendix.

${ }^{160}$ The five fundamental virtues of Confucianism: benevolence 仁, righteousness 義, ritual comportment 䄈, wisdom 智, and faithfulness 信. Rites and music as mentioned below were also upheld by Confucius. This system of "three fives" is further expounded in the Tang scripture Dongzhen taishang basu zhenjing sanwu xingbua miaojue 洞真太上八素 真經三五行化妙訣, DZ 1322 . 
長, were responsible for manifold retributions that emanated from the natural environment. ${ }^{167}$ The Petition for Eradicating Calamities Caused by the River Gods ${ }^{168}$ aims to remedy a case of unspecified adversity, coupled with mental delusion:

We seek to divine whether it is adversity caused by the river god 河神 (i.e., the River Count). Fearing debilitating disease and concerned lest it become acute, [the patron] today places his trust in the Great Tao to make this announcement. He has approached your servant requesting the presentation of a petition for safe passagc through years of decline and months of crisis 衰年厄月 and release from hardships due to Three Rivers adversity 三河之厄. ${ }^{169}$ Your servant promptly prostrates himself to present one petition document, based upon [the patron's] oral deposition 口解:

We humbly pray that the Water Emperors and other gods and Lords of the Three Rivers 三河, Four Seas 四海, and Nine Streams 九江 absolve X from years of decline and months of crisis. ${ }^{170}$ In the Water Bureau 水府, where the register of names 名倸 is kept, may they proclaim his passage and not cause him to be incarcerated in the multiple prisons of hell. ${ }^{171}$ In addition, we request the River Count 河伯 water officials of the Green Emperor of the east, the River Count water officials of the Red Emperor of the south, the River Count water officials of the White Emperor of the west, the River Count water officials of the Black Emperor of the north, and the River Count water officials of the Yellow Emperor of the center, one hundred and twenty persons in each category, to come down and preside over the extirpation of the Three Rivers adversities on behalf of X. We humbly beg the Three Officials of heaven, earth, and water to issue a Nüqing Imperial Edict 女青詔書 ${ }^{172}$ to spare him from suffering and forever preserve him from harm.

\section{The household}

Kinship issues, in particular ancestral relationships, run through petitions of all kinds. And many petitioners in Master Red Pine's almanac draw dependants into their supplications. In the following examples, by contrast, the main beneficiary of the ritual is the domestic group as a whole 周門 or a particular member of the patron's household. Although the word "family" 家 is frequently employed in

${ }^{167}$ Chisong zi zhangli 3.22b; see also 3.5a and 6a and Taishang xuanci zhubua zhang $2.7 \mathrm{~b}$. 168 "Bahe zhang 拔河章," Chisong zi zhangli 5.15a-16a.

${ }^{169}$ Probably referring to the Yellow 黄河, Huai 淮河, and Luo 洛河 rivers.

170 This group of deities features in Nüqing guilü 2.4b. There the Demon of the Four Waterways 四港鬼 takes the place of the Lord of the Four Seas.

${ }^{171}$ The realm of the third of the Three Officials, who were also titled Heaven Official, Earth Official, and Water Bureau Offical 天官地官水府宣 (Chisong zi zbangli $3.20 \mathrm{~b})$. Prayers were made to this bureau for forgiveness of all offences committed against water deities (Wushang biyao 54.19a). It was specifically a place of sin registration and judgment (ibid., 9.8a).

${ }^{172}$ Also called “Statutes and Ordinances of the Nüqing Imperial Edicts" 女青詔書律令 (Chisong zi zhangli 5.33b). In Han times, such edicts were issued by the Emperor of Heaven 天帝 for the protections of tomb inhabitants. See Seidel, "Traces of Han religion," pp. 39-42, and below. 
these petitions, the focus is on this larger community, which comprises dependants, servants, and even domestic animals.

\section{Domestic misfortunes}

Like tombs, the homes of the living and the fortunes of their inhabitants were unsettled by taboo violations. The examples here include offences against the spirits of the earth caused by construction work or alterations, and pollution of the home following births and deaths. The Announcement of Merit Petition for Deletion from the Death Registers of Mt. Taishan ${ }^{173}$ attributes the household's malaise to "contrary destiny":

Year after year we suffered setbacks 轗軻, the path of our life is not as desired, and the dwelling is unsettled. Destiny depends on the Twelve Lords of Fate + 二 司命君 under the Emperor on High of August Heaven 皇天上帝. In accordance with the ancient liturgy of the Heavenly Master 天師舊儀, on the auspicious days of the Three Assemblies 三會, may our names be struck off the death register of Mount Tai 泰山死藉 and deleted from the list of death sentences in the Right Tally 右契. ${ }^{174}$

The petitioner requests a transfer of registration to the Palace of Eternal Life 長 生宮 and that "our kin who have preceded us in death be spared distress and be received in Great Fude 福德 where food and clothing are spontaneously provided. ${ }^{175}$ Taboos related to dwellings 室忌 and to violations of the soil 土忌 through earthworks have a long history in China. The Warring States taboo system is documented by archaeological materials from Shuihudi 睡虎地 (third century B.C.). ${ }^{176}$ Under the Han, Wang Chong 王充 (27-ca. 97) criticized the practice of propitiating soil spirits and exorcising misfortune attributed to violations of soil taboos by means of substitute bodies. ${ }^{177}$ Master Red Pine's Petition for Propitiating the Soil ${ }^{178}$ is situated in that very tradition:

Of late, in the dwelling at such-and-such locality, the residence has been inauspicious, inviting misfortunes from the essences of the soil 土精 and the spirits of the earth 地霝 $[\ldots]$. On behalf of [X], I reverently invite the five Lords of Soil Propitiation 謝土君, five Lords of Earth Control 制地君, five Lords of Soil Absolution 解土君, five Lords of Soil Pacification 安土君, five Lords of Home Stabilization 定宅君, with one hundred and twenty officials and generals

173 “Jue Taishan siji yangong zhang 絶泰山死藉言功章," Chisong zi zbangli 4.23b-24b.

${ }^{174}$ A record kept in the Department of Heaven. See Laozi Xiang'er zhu, 11. 372-373. On the emendations of the registers on the assembly days, see Verellen, "The Twentyfour Dioceses," pp. 41-42.

${ }^{175}$ Palace of Eternal Life, cf. the Gold and Purple Effigy Petition above; Fude, a place of immortality; see Zben'gao 6.2a.

${ }^{176}$ See the catalog in Marc Kalinowski, "Les traités de Shuihudi et l'hémérologie chinoise à la fin des Royaumes combattants," T'oung Pao 72 (1986), p. 225.

${ }^{177}$ See Peter Nickerson, "The Great Petition for Sepulchral Plaints," in Early Daoist scriptures, ed. Stephen Bokenkamp, Berkeley: University of California Press, 1997, pp. 242-243.

178 “Xietu zhang 謝土章," Chisong zi zhangli 3.25a-26b. 
each, to descend together on behalf of this household and dispel the sundry spirits of the Five Soils of the Five Directions. ${ }^{179}$

A diagnosis of the causes for the disturbance is followed by a litany of potentially offended soil gods, as well as calendrical taboos governing construction works:

Since the construction of this residence, new and old excavations, the moving of partitions and exchanging of pillars, erection of buildings, earth moving and new construction, leveling and filling, and alteration of passage ways have offended interdictions and taboos arising from the Six Jia 六甲禁忌 ${ }^{180}[\ldots]$ White soil, black soil, yellow soil $;{ }^{181}$ soil emperor, soil king; soil minister, generals of the Soil Bureau 土府, soil gods, subterranean lords and marquis of two thousand bushels; ${ }^{182}$ yin soil and yang soil, fours seasons and Five Phases, and supreme sovereign of the center; divine princes of the Five Soils in front of and behind the dwelling, to the left and to the right of the dwelling, and magistrate of the center court [...], gate adjutant 門丞 and door commandant 戸尉, ${ }^{183}$ spirits of the well and the stove; green dragon and white tiger, vermilion bird and dark warrior, flying snake 膡蛇 and crouching dragon 伏龍, Taisui, Taiyin, Taiyang, Siming, and taboos related to the twelve branches 十二時辰. ${ }^{184}$

At this point, propitiation is initiated through a directional litany and supplications for pardon invoking the cardinal sectors of the nine palaces 九宮. These were named after four of the eight trigrams 八卦, with the addition of heaven and earth for the center:

For the soil gods of the east who have been offended, [we beg] release and pardon 解 謝 from the Zhen palace 震宮, ${ }^{185}$ for the soil gods of the south who have been offended, release and pardon from the $\mathrm{Li}$ palace 離宮, ${ }^{186}$ for the soil gods of the west who have been offended, release and pardon from the Dui palace 兌宮, ${ }^{187}$ for the soil gods of the north who have been offended, release and pardon from the Kan palace 坎宮, ${ }^{188}$ and for the soil gods of the center who have been offended, release and

179 These deities partially correspond to the pantheon in Zbengyi fawen jing zbangguan pin 3.4a-b (Earth Control) and 3.2b (Soil Absolution). For Earth Control, see also Dengzben yinjue 3.19b-20a and Daoyao lingqi shengui pin jing $1 \mathrm{a}$.

${ }^{180}$ See the introduction above.

${ }^{181}$ For these soil deities, see Nüqing guilü 2.4a.

${ }^{182}$ The annual salary, in grain, corresponding to the rank of a Han commandery governor. Cf. the "grave governors" mentioned below.

${ }^{183}$ For these door gods, see also Yuanchen zhangjiao licheng li $1.20 \mathrm{~b}$.

${ }^{184}$ The directional emblematic animals and stellar gods refer to calendrical household taboos. Cf. Chisong zi zhangli 2.2a, 5.13a, and 2.10b-11a. Many of the same domestic deities are propiliated in the Tang Offering for the Dwelling, Zhengyi jiaozbai yi 正-醮宅儀, DZ 801.

${ }^{185}$ Zhen is the trigram representing the eastern quadrant. For this and the following, see the diagram in Marc Kalinowski, "La transmission du dispostif des Neuf palais sous les Six dynasties," in Tantric and Taoist Studies, vol. 3, ed. M. Strickmann, Brussels: Institut Belge des Hautes Etudes Chinoises, 1985, p. 774.

${ }^{186} \mathrm{Li}$, the palace of the Red Emperor, represents the south in the disposition of the nine palaces.

${ }^{187}$ Dui, the trigram and palace representing the west.

${ }^{188}$ Kan, the trigram and palace representing the north. 
pardon from Qian 乾 and Kun 坤. ${ }^{189}$ As for the Gen 艮, Xun 巽 and other palaces, ${ }^{190}$ may they all bestow their gracious pardon, may the evil spirits and old emanations of east, west, north, and south with all their baleful harm be expelled at once and the household of $\mathrm{X}$, young and old, forever enjoy protection and blessings.

Master Red Pine's almanac circumscribes this domestic group as a ritual entity, for example, when it discusses birth and death pollution. These occurred when a member of the household passed away or gave birth. Although the degree of pollution was graded according to rank, all members alike, including dependants, children, slaves, and domestic animals were liable to produce such pollution affecting the household as a unit. ${ }^{191}$ The Petition for Cleansing the Dwelling from Birth and Death Pollution ${ }^{192}$ dealt with this problem:

The household of the military commander of such-and-such county in such-andsuch prefecture, comprising so-and-so many persons, young and old, this day knock their heads to the ground and surrender their lives 歸命 to the Most High. At present, owing to births and deaths in the residence, they fear to have incurred pollution. The harmful exhalations from taboos related to the twelve branches and the current year's personal destiny have invaded the home. Now [the household] has called upon your servant to request the presentation of a petition for the purification of the residence and courtyard. May the birth and death pollution be cleansed away and inside and out be shining bright. Let divine dragons stand guard for the protection of these people.

The invitation of the officials is a directional litany addressed to the Death Dissipating Lords 解殗君 under each of the Five Emperors. As in many exorcistic rituals (cf. the disposal of the silver foil figurines above), the pollution is driven into the water:

May they descend with one hundred and twenty officials and generals to bathe and wash these men of flesh 肉人 (i.e., ordinary mortals) to expel their birth and death pollution. Let jade maidens and envoys 玉女使者, with one hundred and twenty officials and generals each, provide true spirit water 真精之水 and five harmonies incense 五和之香 to cleanse and sprinkle the well, stove, et cetera, of the household $\mathrm{X}$. Let major death [pollution] enter the sea and minor death enter the river, let all of the thousand deaths and ten thousand pollutions be swept away in due course.

\section{Women and children}

Judging by the petition inventory at the beginning of Master Red Pine's almanac, more complete versions of the work contained a category devoted to

${ }^{189}$ Qian and Kun, the trigrams representing heaven and earth, as well as the northwestern and southwestern palaces of the jiugong.

${ }^{190}$ Gen and Xun, the remaining two trigrams, represent the northeastern and southeastern jiugong palaces.

191 "Yanhui 陁碳," Chisong zi zhangli 2.23a-b. Cf. the members of the household in the Petition for Eliminating Tiger Plagues above, comprising "male and female, young and old, oxen, horses, and six kinds of domestic animals."

192 “Shengsi jieyan xidang zhaishe zhang 生死解殗洗蕩宅舍章," Chisong zi zhangli $5.11 \mathrm{a}-12 \mathrm{a}$. 
spouses 夫妻. ${ }^{193}$ There were also petitions for praying for offspring. ${ }^{194}$ The most common type, and the only surviving kind in this domain, concerns childbirth, mothers, and infants. The dangers of childbirth were a perennial concern, which since early times produced a specialized medical and ritual literature. ${ }^{195}$ The ritual context of the petitions discussed below is indicated by the following passage from a scripture for protecting the unborn and safeguarding mother and child from baleful influences:

From the beginning of pregnancy until the fullness of ten months, it is right to perform meritorious works in advance, have rituals celebrated, copy this scripture, and make offerings with single devotion. When the month of birth arrives, invite three, five, seven, or ten Taoist masters, either at a temple or at home, suspend and fasten banners, light lamps to shine continuously, burn incense and worship. Circumambulate reciting this "Marvelous Scripture of the Gods of the Sexagesimal Cycle for Protecting the Fetus and Preserving Life" seven times seven times, or one hundred times, or as many as a thousand or ten thousand times. ${ }^{1 \%}$

Among the rituals to be performed is the presentation of the Petition for Protecting the Fetus. ${ }^{197}$ In this petition the future parents " $\mathrm{X}$ and his wife" pray to the guardians of unborn children and lying-in mothers for protection against demonic attacks:

We respectfully invite two Lords Pacifier of the Fetus 安胎君, two Lords Protector of the Fetus 護胎君, two Lords Sustaining the Frail Through Calamity 扶衰度厄君, ${ }^{198}$ and two Lords of Ten Thuusand Blessings for Resolving Calamity 萬福解厄君, ${ }^{199}$ with twelve hundred officers and generals, to descend on behalf of wife $X$ to safeguard her life and her pregnancy and ensure easy delivery. We also invite two Ladies Holy Mother Protectors of the Fetus 保 胎聖母君 with twelve hundred officers and generals on behalf of wife X to guard and protect the center of her Cinnabar Fields of the three principles ㅊ:元丹田之 中, ${ }^{200}$ to repulse miasmal essences 邪精, goblins 鬼鬼, and demon thieves 鬼賊, and to protect and nurture the newborn infant 赤子. May you cause the person

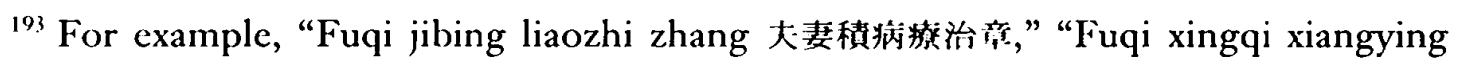
shouguo zhang 夫费與氣相應首過章” (1.7b), and “Fuqi libie duanzhu xiaoguai zhang 夫妻 離別断往消怪章” (1.8a). Zhengyi fawen jing zhangguan pin 2.10b-13b also contains a section devoted to "Healing the sundry diseases befalling men and women 治男女百病."

${ }^{194}$ For example, “Qizi zhang 乞子章” (1.13b).

${ }^{195}$ E.g. the Mawangdui manuscript Taichan shu 胎産葛. See Harper, Early Cbinese medical literature, pp. 27-28.

${ }^{196}$ Taishang shuo liujia zhifu baotai buming miaojing 太上跘六甲淔符保胎謨命妙释（Tang） 2a. DZ 50.

197 “Baotai zhang 保胎章," Chisong zi zhangli 4.12a-13a.

${ }^{198}$ This god is also invoked in Chisong zi zhangli 5.18a. "Sustaining the frail through calamity" was in itself the object of specialized petition rituals. See "Fushuai due baohu zhang 扶衰度厄保護章," Chisong zi zhangli 3.23a-25a, and related titles on 1.6b, 14b, and $15 \mathrm{a}$.

${ }^{199}$ Cf. the petition title "Jiee yanming zhang 解化延命章” on Chisong zi zhangli 1.14a.

200 "Three principles" here refers to the spirits of the three divisions of the body, the Cinnabar Fields. 
of wife $X$ to be safe and to be spared complications, her pregnancy to be protected and the [spirits of] the Six Jia to be settled, so that in the fullness of ten months mother and child will meet each other face to face. That both be granted tranquility, we implore the mighty protection of the great saints of the Gate of Heaven 天門大聖. ${ }^{201}$ May the body of the mother X 某娘 be appeased 和釋 and no vexations arise.

Having arrived at full term, the apprehensive wife $X$ presents another Petition for Expediting Child Delivery to the pantheon of divine midwives and obstetricians. ${ }^{202}$ Though the title translated alternatively "lord" or "lady" is ambiguous, these deities are likely to have been considered female: Lady Gate of Heaven Door of Children 天門子戸君, the Lady Who Speeds Delivery 速生君, the Lady of Wet Nurses 乳母君, the Lady Guiding Delivery 導生君, the Heavenly Physician Assisting Delivery 天醫助生君, and the Lady Expediting Delivery 催生君. To these, wife $\mathrm{X}$ entrusts her approaching confinement:

That the birth may be smooth, avoid complications and follow its normal course, dispel all taboo offenses against the death bringer of the year, the death bringer of the month, and the death bringer of the hour 歲殺月殺時殺, and the lastral demons] White Tiger 白虎 and Xianchi 咸池. ${ }^{203}$ May the thousand miasmas and ten thousand spirits be entirely eliminated, may mother and child be safe, and may all go according to their wish and hearts' desire and free from incidents.

This hurdle passed, the parents' worries are not yet over. In the Petition for the Protection of Newborm Infants and Children, ${ }^{204} \mathrm{X}$ repents his failings and pleads the innocence of his children, having not yet attained the age of reason, who are feared to have fallen prey to the miasmal influences of $\mathrm{Fe}$-cadaver, Wet Nurse 乳母, and the River Count. ${ }^{205}$ The following Superior Radiance Salvation Petition for Infants ${ }^{206}$ was again used in a prophylactic ritual. At the time of the presentation, the child

${ }^{201}$ Cf. Master Red Pine's almanac on the Three Assemblies days, "Sanhui ri : : 會日," Chisong zi zhangli 2.5a: "On these days the Emperor of Heaven and all the great saints 天 帝一切大型 descend together and jointly assemble in the hall of the diocese." On the Emperor of Heaven, see notes 19 and 172 above.

202 "Cuisheng zhang 催生章," Chisong zi zhangli 4.13a-14a. Compare the chapter on “Safeguarding childbirth and pregnancies 保嬰生胎妊” in Zhengyi fawen jing zhangguan pin 2.13b-14a.

${ }^{203}$ On these demons, see Hou Ching-lang, "The Chinese belief in baleful stars," p. 197, n. 10. White Tiger was, and is, especially feared for attacking the fetus in the womb; ibid., pp. 209-219. Cf. Strickmann, Magical medicine, p. 67, on Indian infantsnatching astral demons.

204 “Bao yingtong zhang 保嬰童章," Chisong zi zhangli.4.15b-16b.

${ }^{205}$ On Fei-cadaver, see the Petition for Eliminating Tiger Plagues above. The demon Wet Nurse, associated with river miasmas, also features in the Petition for Protecting the Fetus discussed above (Chisong zi zhangli 4.12b; cf. 4.1b). In the Taishang xuanci zbubua zhang, she is called Wet Nurse of the Water Office 水官乳母 (see 3.1b, 2a, 3a, 3b, and $4.5 \mathrm{~b}$ ). River Count, $\mathrm{He} \mathrm{Bo}$, is both the name of a demon and a prison in the lowest tier of Fengdu (see above).

206 “Xiaoer shangguang duhua zhang 小兒上光度化章,” Chisong zi zhangli 4.14a-15b. 
seems no more than poorly. But fearing worse, the parent appeals for its protection to a resplendent pantheon of lords of light:

We respectfully submit: this day, $\mathrm{X}$, resident of such-and such village, knocks his head to the ground, and states: Karma 宿縁 granted him the good fortune to serve the Great Tao. ${ }^{207}$ Boundless is his rejoicing. Yet $\mathrm{X}$, common and benighted, has wholly failed as a believer and has drawn examination upon himself. Of late, his son $\mathrm{Y}$ suffers confused dreams and thoughts. It is feared they are inauspicious. His four limbs are feeble, and we are concerned lest he contract a severe illness 沈 疴. Not knowing which meritorious acts would be apt to safeguard [the child], $X$ herewith presents his pledge offerings, surrendering himself and depositing his gifts 委質. ${ }^{208} \mathrm{He}$ places his trust in the Great Tao and solicits your servant to supplicate for long life and extended years, that superior radiance salvation 上光 度化 may add to the plenitude of [the child's] years, sustaining his frailty to traverse this calamity 扶衰度厄. Your servant respectfully submits this petition to be conveyed to the Three Heavens Department above. Prostrating ourselves, we pray to the Most High Superior Venerable 太上高尊, to the lord of Supreme Origin 無上元君, to Merciful Father and Holy Mother, ${ }^{209}$ and the senior officials in charge 上官典者. We specially entreat them that all may be well.

We invite the Five Radiance Lords of heaven and earth 天地五光君 and the Five Radiance Lords of the sun, the moon, and the stellar mansions 日月星宿五光君. In the east, we invite sun radiance; in the west, we invite moon radiance; in the south, we invite fire radiance; in the north, we invite water radiance, and in the center, we invite earth radiance. We invite longevity and extended lifespan for his body. We invite the five Lords of Long Life 壽命君, ${ }^{210}$ the five Lords of the Fiery Torch 火炬君, the five Lords of the Three Hun and Seven Po Souls 三魂七隗君, each with twelve hundred officers and generals, to descend and propagate the wonderful medicine of the heavenly immortals 天仙妙藥 and let the qi-energy of Great Harmony 太和之氣 enter the body of Y.211

We further pray for him to recover his complexion, vigor, and happiness. We call on the heavenly officials 天官 to remove him from the death register, to cleanse away his old $q i$, to enter him among the names of the living, to cause his six organs to be in harmony and his five viscera to be settled. May his radiance enjoy the plenitude of long life, let all specters be entirely banished, let his dreams and thoughts be true and correct, his food and drink sweet and delectable, and forever guard his safety. ${ }^{212}$

${ }^{207}$ I.e., the causes and conditions inherited from previous lives. The Buddhist term here takes the place of the more usual formula "mere mortal born from a womb, I was granted the rare good fortune."

${ }^{208}$ Classical etiquette prescribed that to present a gift to a senior, one should set it

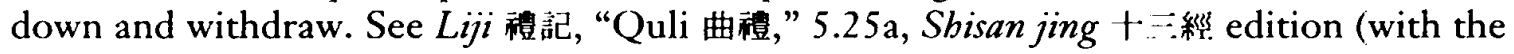
alternative graph 委繁).

${ }^{209}$ See the Petition for Healing Diseases above.

${ }^{210} \mathrm{Cf}$. Zhengyi fawen jing zhangguan pin 1.10a and Chisong zi zhangli, passim.

${ }^{211}$ I.e., the original $q i$ of heaven and earth.

${ }^{212}$ For the formulaic expressions employed in this petition, cf. Taisbang xuanci zbubua zhang 5.1a:「四支煎少。飲食不甘。顔色青黄。魂神離散」。 


\section{The living and the dead}

The idea that the unsettled dead “apprehend living humans" 逮累生人 and that their "emanations seize the living" 注逮生人 points to the permeable boundary between the two communities: ${ }^{213}$ The dead can reach the living and compel them to rectify their grievances or share their burden of suffering. As for the living,

We do not know by which meritorious act the deceased can be redeemed 拔賏 from the gates of darkness 幽關, but we have heard that the Most High Great Tao provides a liturgy of redemption 解拔之科 and rituals for the salvation of the souls of the dead 濟度亡魂之法. Respectfully we offer ritual pledges to the officials of the Five Directions, that they may select the bun and po souls of the deceased for promotion, clear the way, and remove all obstacles 開通道路, 無有空礙. ${ }^{214}$

Thus by means of ritual, the living can also reach the dead, or at least intercede on their behalf. For better or worse, the two spheres communicate. In this final section we will in turn examine petitions seeking to safeguard the living by absolving the dead, to ensure the safe passage of the recently deceased from this world to the next, and to prevent the return of the aggrieved dead among the living.

\section{Absolving the dead}

As we have seen, the recently dead were called to account hefore the Three Officials. Their cumulative culpability, stemming from various sources, was recorded in the registers of sins. Archaeological finds have shown that the term “acquittal from indictment" 解謫 was used in Han tomb ordinances, documents buried with the dead for obtaining their release from netherworld inquisition and punishment. ${ }^{215}$ The Petition for Acquittal from Indictment ${ }^{216}$ lays out the soteriological beliefs, in language close to the ordinances, that induced the bereaved to place such documents in tombs. The ritual could have been performed at the time of the funeral or as part of subsequent tomb-settling rites. The petition begins by recalling that the deceased had invited misfortune upon himself through sin:

In his lifetime, the deceased accumulated numerous sins of the Three Conditions 三業 and Six Faculties 六根. ${ }^{217} \mathrm{He}$ violated the interdictions of heaven above,

${ }^{213}$ Chisong zi zhangli $6.11 \mathrm{~b}, 13 \mathrm{a}$.

${ }^{214}$ Chisong zi zhangli 5.14b. For the last phrase, cf. Liishi chunqiu 吕氏春秋, “Ji chun 季 春," in The annals of Lu Büwei, edition and translation by John Knoblock and Jeffrey Riegel, Stanford: Stanford University Press, 2000, pp. 96-97:「開通道路，無有障塞」。

${ }_{215}$ Seidel, "Traces of Han religion," pp. 42-46. See also Angelika Cedzich, "Ghosts and demons, law and order: Grave quelling texts and early Taoist liturgy," Taoist Resources 4. 2 (1993), pp. 23-35.

216 "Jiezhe zhang 解謫章," Chisong zi zhangli $6.1 \mathrm{~b}-2 \mathrm{~b}$.

${ }^{217}$ I.e., eye, ear, nose, tongue, body, and mind. See also note 64 on the Three Conditions 三業 and Six Senses 六情 above. 
infringed the taboos of earth below, and wronged men and demons in between.

Next, the petitioner invites the appropriate officials, including Lord Great Mystery 太玄君, ${ }^{218}$ to ensure that the soul 魂爽 of the deceased forever depart the Three Destinies 三塗 and escape inscription in the Six Heavens, ${ }^{219}$ praying that the deceased be absolved from all accumulated sin 度脱重罪. Finally, he requests that a Great Mystery True Talisman 太玄真符 be issued to the bureaus under the Three Officials, and a Nüqing Imperial F.dict to the underworld governor, mound magistrate, tomb count, and tombs spirits, as well as all the earth prisons, ${ }^{220}$

To set the deceased entirely free 一切放遣亡人, that he may forever depart the Dark Destinies 永離幽塗 and ascend to the Hall of Blessings 昇遷福堂, where food and clothing are provided spontaneously and he may not lodge miasmal plaints against the living 不得注訟生人.

Like the tomb ordinances, the talisman and edict were missives conveying instructions to the spirits below. In the Petition of Confession, Redemption, and Acquittal on Bebalf of a Deceased, ${ }^{221}$ the Three Heavens Department is implored to repeal the conviction of the accused dead by issuing a Nüqing Imperial Edict to the spirits in charge of the tomb, the prison governors, and the Three Officials, ordering them to "release forthwith the bun and po souls of $\mathrm{X}$, restore his corpse and bones, discharge him from the hardship of penal servitude, and grant him to ascend to the Land of Harmony and Joy 和樂之地 under the administration of the Department of Heaven. Shut off all noxious miasmas 殊注: and delete his name from the register of the dead." The last phrase refers to the miasmal plaints encountered before, i.e. "harm arising from lawsuits 訴訟 within the tombs: they anger heaven and earth, cause the dead to be restless, and disturb the living."222 Tomb plaints 塚訟 form the main subject of two specialized petitions in Master Red Pine's almanac. ${ }^{223}$

${ }^{218}$ One of the officials in charge of mortuary affairs; see Zhengyi fawen jing zhangguan pin 3.2a. The same pantheon is invited in the Petition for Clearing the Way below.

${ }^{219}$ Three Destinies, alternatively written santu 涂 (three mires) or santu $三$ 途 (three gati or paths): referring either to three sorrowful afterlife destinies comprising the hells of fire, blood, and swords; or to the three inferior paths of rebirth as hell being, hungry ghost, or animal. Six Heavens: the realm of demons; see note 46 above.

${ }^{220}$ Cf. the Petition for Eradicating Calamities Caused by the River Gods above and the Petition for Funeral Procession and Burial below.

221 “Wei wangren shouhui shuzui jiezhe zhang 為亡人首梅瞋罪解謫旁," Chisong zi zhangli 6.11a-12b. Cf. Anna Seidel, "Post-mortem immortality or the Taoist resurrection of the body," in Gilgul: Essays on transformation, revolution and permanence in the bistory of religions, Leiden: E.J. Brill, 1987, pp. 232-234.

222 Chisong zi zhangli $4.7 \mathrm{a}$.

223 “Da zhongsong zhang 大塚訟音” and “You da zhongsong zhang 又大塚訟章," Chisong zi zhangli 5.19a-34b. See the translation and study of the first by Peter Nickerson, "The Great Petition for Sepulchral Plaints," pp. 230-274, and Maruyama Hiroshi, "Sei'itsu dōkyō no jōshō girei ni tsuite," pp. 52-60. 


\section{Rites of passage}

The passage of a newly deceased relative from this world to the next, exemplified by the funeral procession, was a moment of vulnerable transition. From the encoffining until the body's transfer to the grave, deceased and survivors alike were exposed to coffin-attacking demons. The Categories of Petitions and Officials has two sections related to this subject, under the headings Averting injury to deceased persons and Safeguarding against the demons of funeral processions and graves. ${ }^{224}$ Master Red Pine's Petition for Clearing the Way ${ }^{225}$ centers on the first step in the ritual process, the encoffining:

The tombs and residence of $\mathrm{X}$, in decline and unlucky, are invaded by spirits and demons. Misfortunes descend upon those who invite them and extend back to their dead. In the year such, in such-and-such month, day, and hour, as a result of contracting a disease that proved severe and incurable $[\mathrm{X}]$ passed away. In accordance with the common rites, he lies encoffined 棺殮 in the main hall. The fate of the bun and po souls of the recently deceased is unfathomable, nor do we know to which path of transmigration 託生 he has been committed. ${ }^{226}$ It is feared that in his lifetime he may have taken the lives of sentient beings 策生 or harmed living creatures. Confined to the Three Destinies 三途, he has not yet been granted deliverance 解脱. ${ }^{227}$

Another ritual aimed to secure the passage of the body to the burial place by presenting this Petition for the Funeral Procession and Burial: ${ }^{228}$

On such-and-such day/month/year, the deceased $X$ passed away to [face] the Three Officials. ${ }^{229}$ Mourning was held in his residence at such-and-such locality. Burial has not yet taken place. On such-and-such day/time of this month, the coffin 屍板 of $\mathrm{X}$ will be in transit from such-and-such locality to such-and-such burial place. $X$ was a devotee of Pure Realization 清畺, who surrendered himself

224 “Shou siren haohai 收死人耗㕩” and “Shou zangsong zhongmu gui 收葬送冢墓鬼,” in Zbengyi fawen jing zhangguan pin 1.13a-15a and 3.1 a-3b, respectively.

225 “Kaitong daolu zhang 開通道路章," Chisong zi zhangli 5.14a-15a.

${ }^{226} \mathrm{Cf}$. the version in Chisong zi zhangli 5.10a: "Since the recent passing of the deceased, we do not know the path of transmigration of his bun and po souls 未知亡人新逝 已來, 魂魄託生何道.”

${ }^{227}$ Three Destinies, see n. 219 above. The word "deliverance" here is one of the Chinese terms for nirvāna.

228 “Chusang xiazang zhang 出喪下葬章," Chisong zi zbangli 6.17a-18a. Peter Nickerson, in "Shamans, demons, diviners, and Taoists: conflict and assimilation in medieval Chinese ritual practice (c. A.D. 100-1000)," Taoist Resources 5.1 (1994), p. 48, cites the following passage as evidence of a Heavenly Master rejection of discipleship, divination, and taboo observance. In my reading, the text would seem to indicate the contrary. A subsequent phrase in the same petition (not reproduced here), translated by Nickerson as "when sending off and burying the dead he taboos and avoids nothing," refers to the dead client's own funeral arrangements, which the priest certifies to have incurred no taboo violations 送終葬死, 無所忌諱 $(6.17 \mathrm{~b})$.

${ }^{229}$ Cf. the expression "after death, he is detained [for trial] by the Three Officials 没命 之後, 囚閉三官” in Chisong zi zbangli 6.1 a. 
to the power of the Tao 道氣, but no longer followed a master 不復從師. ${ }^{230}$ Divination 卜問 leads us to fear that he will suffer harm from [violations of] the thousand interdictions and ten thousand taboos pertaining to the General of the Great Year, the twelve lunar counter-stars 月建, ${ }^{231}$ incarcerating slayers 銁形破 殺, ${ }^{232}$ and the stale emanations of the lower ranks 下官故氣.

The invocation implores five Lords Great Simplicity and Great Commencement 太素太始君, ${ }^{233}$ with a hundred and twenty officials and generals, and twelve burial clerks 葬埋吏 ${ }^{234}$ to send down a fu-talisman to establish command 攝下 and a Nüqing Imperial Edict addressed to the underworld governor 地下二千石, ${ }^{235}$ mound magistrate 丘丞, tomb count 墓伯, marquis of tombs 塚侯, and officials in charge of interdictions and taboos pertaining to thoroughfares, lane boundaries, and the median of the road, that these may not attack the family of $\mathrm{X}$.

Returning to the Petition for Clearing the Way, we find that it, too, invokes Lord Great Mystery 太玄君 with his staff ${ }^{36}$ plus the general-in-chief Plain Hearse and White Horse 素車白馬大將軍, protector of funeral processions. ${ }^{237}$ The petitioner also requests the usual communication of a talisman to the Three Officials and of the Nüing Edict to the tomb spirits and administrators of the "goals and sundry prisons" 年檻諸獄. Following this, the text evokes the bathing and purification that precede the soul's ascent to paradise. These purgatorial procedures form the main subject of a separate group of petitions devoted to ablutions and conveying the deceased's clothing and effects to the netherworld. The bathing, capping, and girding of the deceased constitutes a rite of investiture, representing the passage of

${ }^{230}$ A commentary to a passage in Lu xiansheng daomen keliue 6a-b, criticising those who neglect instruction through proper affiliation with a master, addresses this kind of situation: "A person originally worshiped the Tao, but having long ago lost his master failed to renew his affiliation 人先雖奉道, 失師來久, 不復更属.”

${ }^{231}$ I.e., the lucky or unlucky stars to which the handle of the Northern Dipper points in a given month, during the course of its annual rotation around the pole star. By this measure, each month is correlated with the sector of the corresponding Earthly Branches. In Master Red Pine's almanac, the baleful effects of Great Year (see above) are frequently associated with these conjunctions. See also Zbengyi fawen jing zhangguan pin $3.5 \mathrm{a}$.

${ }^{232}$ For gou 鈎, read $j u$ 拘: see Chisong zi zhangli 3.26a and 6.10a; cf. Zhengyi fawen jing zhangguan pin $3.9 \mathrm{~b}$.

${ }^{233}$ Two of the "three beginnings" (of cosmic energy, form, and matter); see Qianyuan zi sanshi lun 乾元子“始論, DZ 268. This and much of the following invocation parallels Zhengyi fawen jing zhangguan pin 3.4a.

${ }^{23+}$ The Zhengyi fawen jing zhangguan pin speaks of “burial soil gods 葬埋土公” (1.14b) and “burial demons 猆埋之鬼” (3.1b).

${ }^{235}$ Literally, "two thousand bushels of grain." See note 182 above.

${ }^{236}$ Zhengyi fawen jing zhangguan pin 3.2a. The same pantheon and hells are also invoked in the Petition for Acquittal from Indictment, "Jiezhe zhang 解謫章," Chisong $z i$ zhangli $6.1 \mathrm{~b}-2 \mathrm{~b}$ and above.

${ }^{237}$ See Zhengyi fawen jing zhangguan pin 1.13a and 3.3a (Plain Hearse and White Horse, here titled "lord") and 3.2a (Great Mystery). 
the tormented soul to a state of felicity. ${ }^{238}$ Again, archaeology suggests the proximity of the petition ritual to Han funerary practices. The Petition on Sending the Clothes and Effects of the Deceased and for Obtaining Transfer through Acquittal from Indictment ${ }^{239}$ shares key terms with the excavated tomb documents:

We offer the attire of $\mathrm{X}$ [worn] in his lifetime, consisting of such-and-such kinds of clothes and effects 衣物, ${ }^{2+0}$ in order to buy back the bun-soul of X from severe chastisement in death. [...] Let the [sundry prison authorities] release the bun and po souls of $X$, wipe out the charges leveled against him, annul his condemnations, and set him free from prison, his sentence fully served. Bathed, capped, and girded 沐浴冠帯, let him be promoted to the Hall of Blessings 福堂. Let him revert to the womb for reincarnation, and may he return in a worthy household 善門!

Like the expression "acquittal from indictment," the term "clothes and effects" links these petitions to excavated funerary documents from the Han. A clothes and effects deed 衣物券 accompanied the inventory of grave goods buried with the deceased..$^{2+1}$ An exemple dated $\mathrm{AD} 361$, from the tomb of Zhou Fangming 周芳命 at Changsha, refers to the "personal clothing and effects accompanying her to the grave" 其隨葬衣物. ${ }^{242}$ The wording of the Ablutions Petition ${ }^{243}$ is ambivalently poised between such concrete burial practices and the metaphors of redemption: ${ }^{2+4}$

We respectfully consider that the deceased, since passing away bearing a lifetime's burden of sundry transgressions, is held in detention by the Three Officials. Amid dire sufferings, he has not yet bcen granted deliverance. Today we can but place our trust in the power of the Great Tao to rescue his bun souls from darkness. To

${ }^{238}$ Kristofer Schipper described it as an initiation. See The Taoist body, translated by Karen C. Duval, Berkeley: University of California Press, 1993, p. 77.

239 “Ji wangren yiwu jie zuizhe qianda zhang 亡人衣物解罪謫㟟達章," Chisong zi zhangli $6.12 \mathrm{~b}-14 \mathrm{~b}$.

${ }^{240}$ Cf. the near-identical phrase in an inventary list from a Jin tomb at Changsha dated 361, in Albert E. Dien, "Turfan funereal documents," Journal of Chinese Religions 30 (2002), p. 31.

${ }^{241}$ See Ikeda On 池田温, “Chūgoku kodai bosō no ikkōsatsu: zuizō ibutsuken ni tsuite 中國古代墓葬の一考察: 隨葬衣物券について,”Kokusai tōbōgakusha kaigi kiyō 國際東方學者會 議紀要 6 (1961), pp. 51-60.

${ }^{242}$ See Hunan sheng bowu guan 湖南省博物館, “Changsha liang Jin Nanchao Sui mu fajue baogao 長沙兩晋南朝隋幕發掘報告,” Kaogu xuebao 考古學報 1959.3, p. 88, and translation in Albert E. Dien, "Turfan funereal documents," p. 31.

${ }^{2+3}$ “Muyu zhang 沐浴章," Chisong zi zhangli 6.1 a-b.

${ }^{24+}$ The early Buddhist scripture Fo shuo wenshi xiyu zbongseng jing 佛説温室洗浴衆僧經, T. 16, no. 701, 802c, translated by An Shigao 安世高 (fl. AD 148), advocates personal hygiene simultaneously as a universal cure for disease 十方鼻藥療病, and as a means for appeasing the dead, cleansing away pollution, and averting peril 令衆生長夜清淨, 穢垢消 除, 不遭衆患. In later Buddho-Taoist texts, the moral and redemptive meaning of ablutions becomes increasingly evident. See Cheng Cunjie 程存潔, “Dunhuang ben Taisbang lingbao xiyu sbenxin jing yanjiu 敦煌本《太上露寶洗浴身心經》研究,” Daojia wenhua yanjiu 道家文化研究 13 (1998), pp. 295-309. 
cleanse away 蕩涤 the sins 饻尤 of his former karma 宿業, ${ }^{245}$ we now respectfully convey the clothes and effects 衣物 of the deceased in his lifetime, as well as settling-pledges 鎮信 including money, rice, incense, oil, directional silks 方綵, ${ }^{2+6}$ brushes, ink, and others. We request that a bathing hall 浴堂 $^{2+7}$ be set up in the pure court 淨庭. ${ }^{248}$ Let the bathing utensils all be bright and clean, and let [the deceased] be absolved from the mire of darkness 幽塗. ${ }^{249}$ Humbly prostrating ourselves on the ground, we present this petition and send up our request to the Lord and Officers of Ablutions 沐浴君吏, the Lady of Ablutions 沐浴夫人, the Jade Washing Maidens 洗浣玉女, twelve hundred persons, to administer the bathing of the deceased's bodily form, to wash away his stains and eliminate his impurities, to remove his shackles 桎梏 and let him behold the bright light, roam in happiness where clothing and food are naturally provided and nothing is wanting. And may his tomb be settled and blessings be conferred upon the living.

\section{Land of no return}

Tomb-settling rituals and documents seek to prevent the return of the dead among the living. ${ }^{250}$ The title of the Petition for Propitiating the Five Tombs ${ }^{251}$ alludes to the five-fold classification and orientation of tombs by family name, where each name is associated with one of the five musical tones, and hence with a direction of space. ${ }^{252}$ We learn that the patron of the ritual has contracted a lifethreatening disease, due to his family's legacy of sin or to the grievances of its dead. Disturbing the grave through encroachment, the felling of trees, or other damage to the site and its environment might cause such grievances. The petitioner thoughtfully entertains the possibility that the dead could be merely nervous about such damage occurring in the future. He accordingly appeals for the pardon of his deceased ancestors and the pacification of their tombs, emphasizing geomantic and other taboo considerations:

${ }^{245}$ For the soteriological overtones of the word dangdi, cf. Lu Xiujing on Zhang Daoling's “cleansing of the universe 薄涤宇宙” (Lu xiansheng daomen keliie $1 \mathrm{~b}$ ).

2th I.e., offerings of silks in the colors corresponding to the five directions. Cf. Chisong zi zhangli 1.2b-3a: “five directional silks according to the directional colors ti方綵籍方色."

${ }^{247}$ In Fo shuo wenshi xiyu zhongseng jing $802 \mathrm{c}$, the holy assembly is enjoined to enter the “warm room" to perform their ablutions 入温室澡浴.

${ }^{2+8}$ Perhaps associated with the pure room or oratory 鋖室; cf. Beidi qiyuan ziting yansheng bijue 北关七元紫脠延生秘䚿 (Tang or Five Dynasties) 5b, DZ 1265, where the Perfected descend to an adept's "pure court."

2+9 Equivalent of "infernal routes" 幽途. This refers to the three evil paths of rebirth as hell creature, hungry ghost, or beast (cf. note 219 above).

${ }^{250}$ Chisong zi zhangli $4.17 \mathrm{~b}$.

251 "Xie wumu zhang 謝五墓章," Chisong zi zhangli 4.7a-9b. For a full translation, see Cedzich, "Das Ritual der Himmelsmeister," pp. 85-90.

252 On "pentatonic orientation" 五音向, see Chisong zi zhangli 5.22a, 32a, commentary on $5.31 \mathrm{~b}$, and almanac indications on $1.20 \mathrm{a}-22 \mathrm{a}$. For the full term "tombs of the five-

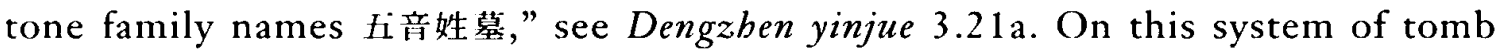
orientation, see also Yuanchen zhangjiao licheng li $2.6 \mathrm{~b}-7 \mathrm{~b}$ and Strickmann, Magical medicine, pp. 30-31. 
Whether the tomb is situated at the head or the tail of the dragon, at the left or the right of the dragon, or whether it is situated at the feet of the dragon, if [earth works] raising or moving, reducing or enlarging, twisting or turning have occurred in places of interdiction and taboo avoidance, thus agitating the bun and the po souls of the dead and terrifying and unsettling them so that they return to harm the living by causing distress 輸軻 and the spread of diseases 疾病 附注, let all of this be annulled. May the Five Tones mound magistrate 五音兵. 丞, the tomb count, and the grave governor terminate all inquisitions emanating from tombs. ${ }^{253}$

We have already considered taboo violations arising from pollution in a domestic setting. Such pollution occurred inevitably in the wake of births and deaths and lasted for graded periods of time. ${ }^{254}$ The Petition for Sprinkling the House of a Newly Deceased, ${ }^{255}$ by contrast, was used in a ritual for cleansing the dwelling of pollution caused by the miasmal return of the recently dead:

Since the present year, the residents of this household have been afflicted by adversity 轗軻. There has been a series of deaths. X fell ill and died in such-andsuch month/day. It is feared that on the day of the death of $\mathrm{X}$ a miasmal return among the living 注復生人 took place. There is an evil emanation of soil calamity 土殊. The demons of the hearse 垡車, ${ }^{256}$ the zhuoshen 魅魅, ${ }^{257}$ and the malefemale demons 雄雌之鬼 ${ }^{258}$ have settled inside the residence, causing incessant harm and plunder. The humans 约人 tremble with fear, unable to recover their nerve. They have brought the case before your servant requesting him to drive out the miasmal death bringers 注殺 from the residence, calm the spirits, and stcady the $q i$. I respectfully submit as related.

Tao Hongjing 陶弘景 (456-536) explains the situation as follows: "In extreme instances of family deaths involving parents, brothers, and spouses, there can be a subsequent reversion of miasma returning to the living 後還注復生人 and causing them bodily harm." 259 From Master Red Pine's almanac we learn, through a further twist of the theory of bun and po souls and their destiny after death, that it

${ }^{253}$ Chisong zi zhangli 4.8a.

${ }^{254}$ For adult kin, the period of death pollution was determined by the prescribed degree of mourning. Shorter periods applied to children, slaves, and animals. Cf. note 191 above.

255 “Xinwang sazhai zhuzhu quesha zhang 新亡政先逐注钢殺章," Chisong zi zhangli $6.20 \mathrm{a}-21 \mathrm{~b}$.

${ }^{256}$ Taishang xuanci zhubua zhang 3.11 a speaks of "death-dealing demons following the funeral carriage 次践車殺鬼.” The Nüqing demonology, the probable source of the present enumeration, also lists funeral carriage demons together with zhuoshen demons, as well as earth calamity 地殊 and male-female demons in the same category. See Nüqing guilï $6.7 \mathbf{a}$.

${ }^{257}$ Zhuo is one of the stars of the Dipper. The graph 魅 appears to be a variant of shen 鬿, which the Shuowen jiezi 説文解字 defines as shen 神.

${ }^{258}$ These are the "essential $q i, y i n$ and yang, of the female and male bun and po souls 陰 陽倠雄魂魄之精然.” See the Tang treatise Taishang laojun xuwu ziran benqi jing 太上老君虚 無自然本起經 10b, DZ 1438, and below.

${ }^{259}$ See his commentary in Dengzben yinjue $3.20 \mathrm{~b}$. Several petitions in Red Pine's almanac deal with this problem; see 4.17a, 6.19a-b, and below. 
is the newly deceased himself who returns to attack his family through demonic transformations of these souls:

Your servant observes that on the day a person dies, his bun and po souls scatter. They transform into eight death dealers 八殺, the respective male and female miasmas 倠雄各注, ${ }^{260}$ and the hearse and zbuoshen [demons]. Emerging or arising, they return to inflict their deadly harm and entangle 纏綿 the residents. If they find these lacking in their attentions, they will desire to inflict further damage, visiting the living with miasmal injury 注害.

The priest requests the aid of divine sprinklers of holy water to cleanse the residence of the malevolent emanations:

We invite lord Qinqi 离奇君 ${ }^{261}$ together with the Shuitan clerk 水坦吏 to descend into the living quarters of the household $\mathrm{X}$ to arrest the miasmal demon $F e i$-cadaver, ${ }^{262}$ female and male visiting death dealers 客殺, ${ }^{263}$ and the hearse and zbuoshen-demons. Let these be entirely obliterated [...]. We further invite bearers of holy water 神水使者 to join forces with the invited officials to sweep and sprinkle holy water within the residence. ${ }^{264}$ May they voyage ten thousand $l i$ through the clouds to freshen and purify the inside of the dwelling and wash away and eliminate the corpse pollution.

A continued connection with dead relatives could result in chronic infection among living family members, as explained in this Petition for Preventing Reconnection with the Dead: ${ }^{265}$

Today we knock our heads to the ground and declare: An ordinary being born from a womb and issued from the lower ranks, I was granted the rare good fortune to serve the Great Tao. Veritable are my joy and my comfort!

In good faith, $X$ incurred a violation of the codes and brought misfortune upon himself. On such-and-such a day of this month, X contracted a severe illness 染疾 困重. His thoughts and dreams are confused and he has ungodly visions. We seek to divine whether the dead are causing his misfortune by reestablishing contact 更 相復連, thus endlessly perpetuating this disease. We fear that as long as the dead are not isolated, the contagion can never be stopped 死亡不絶注復不断. The whole family is fretful, fearing the patient may not survive. This day, speaking

${ }^{260}$ Cf. Taishang xuanci zhubua zhang $3.11 \mathrm{a}$, "male and female miasmas of the recently dead and the long deceased 新死故 ᄂ.雄瞧注," and ibid., 3.5b on "male and female cadaver calamities 男女ץ歼.”

${ }^{261}$ In the liturgical protocol Taishang sanwu zbengyi mengwei yuelu jiaoyi 太上三五正一 盟威閲策醮儀, edited by Du Guangting 杜光庭 (850-933), 5a, DZ 796, a general of that name is invoked for exorcistic purification. He is also listed in the Tang collection of ordination and prophylactic registers Taishang zhengyi mengzei falu yibu 太 1 : 1 : 盟威法籍 一部 10a-b, DZ 1209.

26. See the Petition for Eliminating Tiger Plagues above.

${ }^{263}$ Cf. Taishang xuanci zhubua zhang $3.11 \mathrm{a}$ : "the evils of roaming disaster and visiting death dealers 遊殊客殺之厄.”

${ }^{26+4}$ For a catalog of such supernatural waters, see the section "Shenshui pin 神水品" in Wushang biyao 4.14b-15b and John Lagerwey, Wu-shang pi-yao: somme taoiste du VIe siècle, Paris: École Française d'Extrême-Orient, 1981, p. 77.

265 “Duan wangren fulian zhang 断亡人復連章," Chisong zi zhangli 4.16b-18a. 
earnestly from the heart, they have turned to your servant to request his recovery. Promptly presenting one petition document on their behalf, I beg to submit...

The petitioner goes on to implore 100,000 Lords of Personal Destiny 本命君 to dissolve the $q$ i-exhalation of the reconnected dead 亡人復連之氣, praying for "disconnection" 断絶 and that the souls of the departed remain widely separated from the living, for

The living belong to August Heaven 皇天 and the dead to the Yellow Springs 黄 泉. The living and the dead follow separate paths 生死恭路, ${ }^{266}$ and the person of $\mathrm{X}$ must not be disturbed... ${ }^{267}$

Praying for the liberation of the anonymous sinner's incarcerated soul and its transfer to paradise so that "the tomb may be settled, the lawsuit cleared, and the disease of X cured," all as a result of severing the reconnection, this petitioner underscores the seamless association of Heavenly Master healing with salvation. ${ }^{268}$

\section{HEALING OR REDEMPTION?}

According to the introduction to Master Red Pine's almanac, Lord Lao revealed his original petition models and other holy writings to Zhang Daoling as a "saving remedy for mankind" 救治人物. Taoism developed its salvific program of healing and liberation at the same time as Buddhist rituals for the redemption of the dead gained ground in China. The early apocalyptic outlook of the diocesan community envisaged salvation as inscription among the "seed people for the world to come" 後 世種民. ${ }^{269}$ Yet Master Red Pine's petitions allude to this vision as a mere figure of speech, ${ }^{270}$ and less currently than to karmic metaphors of salvation.

Another distinctively Taoist concept of salvation is the quest for transcendence from the mortal realm. Red Pine's almanac includes a petition by an advanced initiate in the categories of Taoist scripture that were progressively transmitted to adepts at different levels of ordination: Laozi's Way and its Virtue, the canonical Three Caverns devised by Lu Xiujing 陸修靜 (406-477), plus another associated with the "Scripture of Divine Incantations."

I was favored to receive Lord Lao's "Five Thousand [Characters] Text on the Way and its Virtue” 道德五千文, the venerable scriptures, and the methods of the

${ }^{266}$ Echoing a characteristic sentiment of Han tomb ordinances, see Seidel, "Traces of Han religion," p. 31.

${ }^{267}$ Chisong zi zhangli $4.16 \mathrm{~b}-17 \mathrm{~b}$.

${ }^{268}$ See also the Petition for Clearing the Way for the Transfer of a Recently Deceased, for Propitiating Harm to the Soil Calamity, and Interdicting Reconnection, "Xinwang qianda kaitong daolu shouchu tuyang duanjue fulian zhang 新亡遷達開通道路收除土殊断絶復連 章," Chisong zi zhangli 6.18a-20a.

${ }^{269}$ Dadao jialing jie 15a. Cf. Verellen, “The Twenty-four Dioceses," pp. 43-46.

${ }^{200}$ See Chisong zi zhangli 4.10b, 23a; 5.5b, 6b.

${ }^{271}$ Taishang dongyuan shenzbou jing 太上洞淵神咒經, DZ 335. See Christine Mollier,

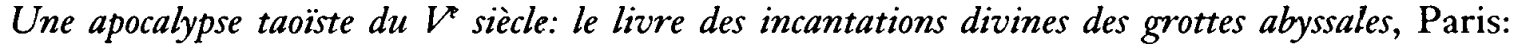
Collège de France, 1990. Although they originated in a sectarian environment, these texts were close in spirit to the Heavenly Master methods. 
Dongshen 洞神, Dongxuan 洞玄, Dongyuan 洞淵, and Dongzhen 洞真 caverns, among others. On the day I was honored to receive these, I vowed to worship the precious writings, to practice merit and establish virtue; to act in conformity with the divine immortals, long life and transcendence 度世, and life everlasting. Even if I do not attain transcendence as an immortal, I shall commit my soul 詑命 to Taiyin 太陰 for smelting and rebirth as a Perfected and to escape the Three Destinies 三塗. ${ }^{272}$

This combination of alternative afterlife prospects is not unusual for the Chisong $z i$ zhangli. The presentation of a petition for an adept's transcendent salvation, on the other hand, is exceptional. Prayers for salvation concern almost invariably the dead and, more particularly, the dead as a source of contagion and misfortune befalling the living. To recapitulate, Heavenly Master soteriology according to Master Red Pine can be resumed as follows:

1. To be born human is to incur liabilities through violation of moral precepts, indistinctly transmitted guilt, infractions of taboos that inextricably adhere to the environment, the stars, and the very divisions of time and space.

2. Death is incarceration in a realm of darkness, where sinners are held to account for their recorded liabilities. The departed tend to harbor resentment against the living, including surviving kin.

3. In addition to sufferings endured from inquisition and penal service, the dead undergo vexations due to unresolved grievances and ongoing infringements, such as violations of the tomb sphere.

4. The petition ritual, by the efficacious power of the written word and the supplicant's sincerity expressed through acts of contrition and faith offerings, provides a means to obtain acquittal and release for the convicted dead.

5. Full acquittal promotes the dead to a carefree existence in a hall of light where their vengeful inclinations are appeased. The interceding family may stipulate that the redeemed ascendant shall be barred from pursuing the living.

The salvation of the dead thus forms part of an apotropaic ritual program based on redemptive techniques for absolving culpability and untying astrological and other "binds," such as taboo conflicts and spells. Far from the sublimated Six Dynasties theories of Taoist immortality, these techniques are rooted in ancient occult methods of spellbinding and exorcism, antithetical procedures associated with the juridical concepts of jie 詰, "accusation," and jie 解, “acquittal." ${ }^{273}$ They serve as instruments for curing or pacifying the various ills and crises experienced at different communal levels by the Heavenly Master community. Healing requires expiation, and disease is but one among many forms of retributive sufferings, reverses, and infestations to be resolved by redemptive measures. The petitions bring to life a society pursuing its everyday activities under the shadow of multiple and indeterminate liabilities, answerable in this life and the next. As may be expected in a framework of apotropaic ritual, many petitions are prophylactic in nature, seeking to avert evil influences that are dimly apprehended through visions or divination.

272 “Shangqing yangong zhang 上清言功章," Chisong zi zhangli $4.20 \mathrm{a}-21 \mathrm{~b}$.

${ }^{273}$ See Harper, "A Chinese demonology," pp. 470-479, and above. 
The Taoism of Master Red Pine's petition manual shows notable continuities with practices of pre-Heavenly Master Chinese religion, especially in such areas as funerary ritual, almanac divination, demonology, and the bureaucratic organization of the unseen world. At the same time, it shares many of the contradictions inherent in an evolving, multi-faceted religious system. The ancestor cult, for example, is traditionally held to ensure the harmonious regulation of relationships between generations and across the divide of death, on a basis of filial piety. The cult enables the living members of a family to enjoy the blessings and protection of benevolent dead ancestors, in exchange for continuous devotions and offerings. In Red Pine's petition almanac, by contrast, ancestors appear as vengeful demons, prepared to attack their own kin at the moment of death, and as unremitting sources of contagion and misfortune thereafter. Early Heavenly Master Taoism was fundamentally preoccupied with disease, which it interpreted in large part as a failure to break connections between the living and the dead. On these grounds, both the ancestral cult and medicine were initially rejected. ${ }^{274}$ With the Lingbao renewal of Taoist ritual in the fifth century, the redemptive focus began to shift towards the deliverance of deceased ancestors. This shift accommodated the Buddhist recasting of Chinese filial devotion as the ritual intercession of a celibate sangha on behalf of deceased parents. The innovation betrayed its apologetic and un-Chinese origins in ambivalent attitudes toward suffering ancestors, who were often portrayed as unbelievers and serious sinners, to be saved against the odds. ${ }^{275}$ Master Red Pine's petition almanac reflects these ambiguities.

Another example of discontinuity is the almanac's unorthodox and inconsistent position with regard to the nature of the bun and po souls, their relation to death and disease, the persona they inhabit, and their destiny after death. The petitioner typically stresses his anxious uncertainty as to the whereabouts and ultimate fate of the souls. This is at odds with scholastic theory, but accords with attitudes expressed in Han tomb documents. A dichotomy between popular and literati views has been advanced to explain the divergence. ${ }^{276}$ Intuitively, one may question whether tombs that preserved written funerary documents for two thousand years are representative of the religion of the common people, as Anna Seidel concluded. And if so, do the beliefs expressed in their funerary documents differ significantly from those found in princely tombs, e.g. at Mawangdui, which Seidel cited in much the same vein? I am not competent to answer these questions. Master Red Pine's petition ritual, on the other hand, can be positioned in society with some confidence. Apart from the semi-official background of the drought and agricultural rituals, many of the privately commissioned petitions evoke sizeable

${ }^{274}$ See Michel Strickmann, "Therapeutische Rituale und das Problem des Bösen im frühen Taoismus," in Religion und Philosophie in Ostasien: Festschrift für Hans Steininger, ed. G. Naundorf et al., Würzburg: Königshausen und Neumann, 1985, pp. 189-192.

${ }^{275}$ Cf. Cole, Mothers and sons in Chinese Buddhism, pp. 50-54.

${ }^{276}$ See Anna Seidel, "Traces of Han religion," pp. 21-57, and K.E. Brashier, "Han thanatology and the division of 'souls'," Early China 21 (1996), pp. 125-158. 
households and are accompanied by costly offerings including gold and silver rings, bracelets, and substitute bodies. The petition ritual was from the start conceived as universal: the Protocol of the Twelve Hundred Officials and the Three Hundred Great Petitions distinguished three degrees of petitions, labeled “eminent” 㱜 for the emperor, “senior” 丈 for lords and princes, and “popular” 民 for commoners, with corresponding qualitative and quantitative gradations of pledges. ${ }^{277}$ That this ancient ideal enjoyed some actuality in ritual practice is clear from the following:

In the case of petitions without normative pledges, the well-to-do give more, while the poor give less. When high-ranking and affluent families hope to gain merit but are parsimonious with their wealth, producing pledges worthy of paupers, then no benefit accrues to them. The code states: When the destitute or needy request a petition offering, the master should provide the ritual pledges in their stead. ${ }^{278}$

As for the clergy, even if we adopted the view that it mimicked court and literati culture, it certainly mastered a learned scribal tradition, not to mention scripture and liturgy, cosmology, astrology, and accessory mantic and calendrical arts. In short, the medieval petition ritual is a phenomenon of popular religion only in the sense that it was practiced at all levels of society.

One explanation for the Chisong zi zhangli's multivalent belief system lies, as already suggested, in the incongruity running deep through Chinese religion from the Han onward as a result of the assimilation of Buddhist afterlife conceptions, especially the beliefs in transmigration and karmic causality. These ideas stood in contradiction with the principles of Chinese ancestral worship and beliefs about the separate destiny of a persona's components after death. Meanwhile, Chinese beliefs, such as the theory of bun and po souls, continued to coexist with the suggestive new world view imported from India, despite the growing gulf between religious practice and traditional theory. Significantly, the vacillating references to bun and po souls in petition texts usually occur in conjunction with equally wavering allusions to different forms of rebirth. The same cohabitation of alternative and sometimes incompatible ideas can be observed in Buddho-Taoist moral concepts, especially as regards inherited guilt and retribution for sins. ${ }^{279}$

Of course ideas do not propagate synchronically and homogeneously through culturally diverse societies. Given the inherent conservatism of liturgical genres, and the Chisong zi zbangli's nostalgic harking back to the early Heavenly Master church in Hanzhong, the almanac is perhaps surprisingly reflective of change. On the other hand, its incongruously archaic traits, such as the treatment of ancestors as noxious emanations, were undoubtedly accepted as part of the generic tradition. The reality of Chinese religious practice, whether today or in

277 “Lun sandeng zhang 論 :等章," Chisong zi zhangli 1.18a-b.

${ }^{278}$ Chisong zi zhangli $1.1 \mathrm{~b}-2 \mathrm{a}$.

${ }^{279}$ See Erik Zürcher, "Buddhist influence on early Taoism: A survey of scriptural evidence," T'oung Pao 66 (1980), pp. 129-135. 
history, gives us every reason to assume that medieval patrons of Heavenly Master healing magic also consulted physicians, and that nothing prevented tomb exorcists from worshipping their ancestors at home.

The special interest of Master Red Pine's petition almanac lies in its abundant documentation of religious life across an extended period and diverse sectors of society in medieval China. Despite substantial lacunae, it allows us to form a remarkably complete picture of the Heavenly Master community's ritual methods and concerns, from praying for rain and expelling locusts to sickness and curses, from domestic worries to negotiating the interface between the living and the dead. A handbook for priests, Master Red Pine's almanac of necessity reflects the reality of liturgical practice. And as an agenda of "things to be done," it is largely unconcerned by the theoretical agendas that often imbue writings on ritual. 